\title{
Late Weichselian to early Holocene sedimentation in a steep fjord/valley setting, Visdalen, Edgeøya, eastern Svalbard: glacial deposits, alluvial/colluvial-fan deltas and spit-platforms
}

\author{
PER MÖLLER, OLE P. STUBDRUP and CHRISTIAN KRONBORG
}

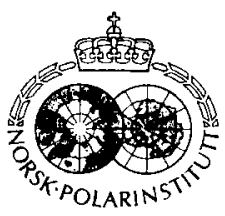

\begin{abstract}
Möller, P.. Stubdrup, O. P. \& Kronborg, C. 1995: Late Weichselian to early Holocene sedimentation in a steep fjord/valley setting, Visdalen. Edgeøya, eastern Svalbard: glacial deposits, alluvial/colluvial-fan deltas and spit-platforms. Polar Research 14(2), 181-203.
\end{abstract}

The Visdalen valley, situated at the northwestern corner of Edgeøya, was investigated with respect to lithostratigraphy and depositional environments of the Quaternary sediments. Eight major lithostratigraphic units are recognised of which seven were deposited during the Late Weichselian to early Holocene glaciation, deglaciation and the subsequent emergence of the area, and one unit deposited prior the last glaciation. Till deposition from a west-flowing glacier was followed by glaciomarine and later marine deposition of fine-grained sediments. Coarse-grained colluvial and alluvial-fan deltas were deposited along the mountainsides in the Visdalen palaeo-bay, and distal sediment gravity-flow deposits from these deltas were interbedded with the glaciomarine-marine sediments. A spit-platform (riegel) was built up across the Visdalen bay contemporaneously with the alluvial fan-deltas. Its formation was time-transgressive, with its highest part in the south close to the marine limit at $85 \mathrm{~m}$ a.s.l. and its lowest part in the north at ca $65 \mathrm{~m}$ a.s.l. The sediment source was alluvial and colluvial debris. which was entrained by longshore currents along the more exposed coast south of Visdalen and transported northwards to the final place of deposition. The bulk part of the riegel ridge is composed of progradational successions of steep foresets dipping towards $\mathrm{NW}, \mathrm{N}$ and $\mathrm{NE}$, and clearly rejects an earlier ice-contact model. Datings suggest that the fan-delta deposition and the riegel formation ended before $9,000 \mathrm{BP}$. A meltwater-fed lagoon with a highest level at $>50 \mathrm{~m}$ a.s.l. was formed behind the riegel ridge in which, according to varve counting. glaciolacustrine sedimentation lasted more than 250 years and occurred within the time span 9,000-8,500 BP. Gradual uplift of the area resulted in drainage of the glaciolacustrine lagoon. Beachface processes and fluvial down-cutting took place during the emergence of the area.

Per Möller, Department of Quaternary Geology, Lund University, Solvegatan 13, S-223 62 Lund, Sweden: Ole P. Stubdrup and Christian Kronborg, Geologisk Institut, Aarhus Universitet, C. F. Møllers Allé, DK-8000 Aarhus, Denmark.

\section{Introduction}

The 1991 PONAM expedition (Polar North Atlantic Margins, Late Cenozoic Evolution) to eastern Svalbard (Barentsøya, Edgeøya and Kong Karls Land; Fig. 1) had the general priority of finding "old" sediments, i.e. sediments predating the Late Weichselian deglaciation of the area. The aim was to reveal the glacial history during the last interglacial-glacial cycle. Indications on the existence of older sediments have been given by Boulton et al. (1982) and Boulton (1990) from the Rosenbergdalen valley on northwestern Edgeøya (ridge 2, Fig. 2). A reconnaissance of the nearby Visdalen valley (framed area around ridge 1, Fig. 2) showed an abundance of fresh exposures and indicated a great potential to reconstruct the deglaciation history and a complex depositional environment during the emergence of the area. Pre-PONAM investigations on Barentsøya and Edgeøya have mostly focused on the altitude of the marine limit and sea level change (Büdel 1968; Glaser 1968; Knape 1971; Boulton 1990). Related to studies on sea-level change are the investigations on transverse valleymouth ridges, which Büdel $(1962,1968)$ in German named a "Riegelserie". These "riegel" ridges are prominent morphological features in many Edgeøya valleys, and one of the largest and best preserved riegel ridges is situated in the Visdalen valley. Another prominent feature of Visdalen is the thick alluvial and colluvial fan deposits along the valley slopes. It was thus quite clear from the 


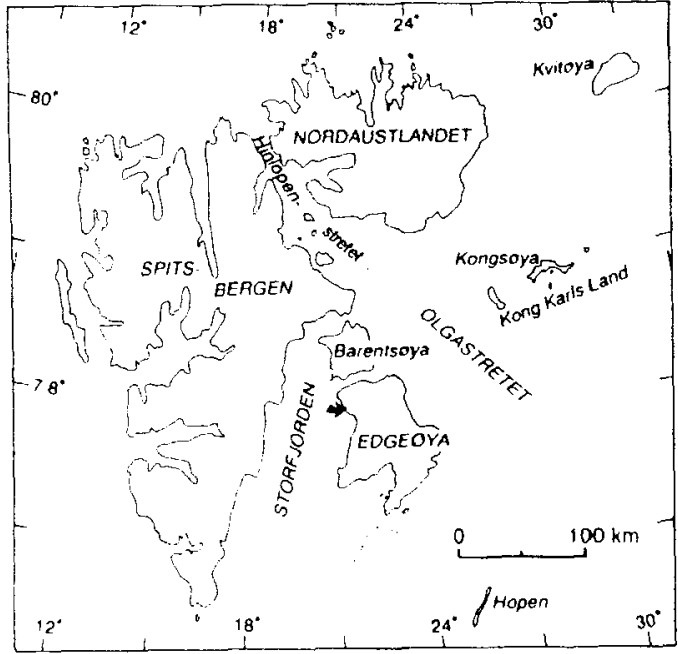

Fig. 1. The Sualbard archipelago. The location of Visdalen is marked by black arrow

start of the investigation that emphasis should be put on the sedimentology of the riegel and fan deposits. With a good time frame by means of ${ }^{14} \mathrm{C}$-datings, it would then be possible to give some answers about sediment dispersal patterns and sedimentation rate of these deposits and how they relate to sea-level change and climate control.

Because there are different opinions about riegel ridge formation, a review of previous investigations is appropriate. The riegel ridges of Barentsøya and northern Edgeøya (ridges 3-10, Fig. 2) were investigated by Büdel $(1962,1968)$, who found them to be situated at or below the now accepted marine limit (80-85 $\mathrm{m}$ a.s.l.; Bondevik et al. 1995) and at or somewhat inside the valley mouths, with an extension sometimes across the whole valley. The ridges were found to consist of marine sand with bivalve shells, sometimes sitting in living position, covered by beach gravel usually forming a well-developed series of raised beach ridges. The riegel ridges on northwestern Edgeøya (ridges 1 and 2, Fig. 2) were studied by Glaser (1968), who gave a more detailed description of the internal sediments. Names (usually informal ones) given to the ridges, the levelled altitudes of their top surfaces and ${ }^{14} \mathrm{C}$ datings of whalebones, given by these authors, are summarised in Table 1.

Büdel (1968) interpreted the ridges as formed on top of "normal" marine sediments by depo-

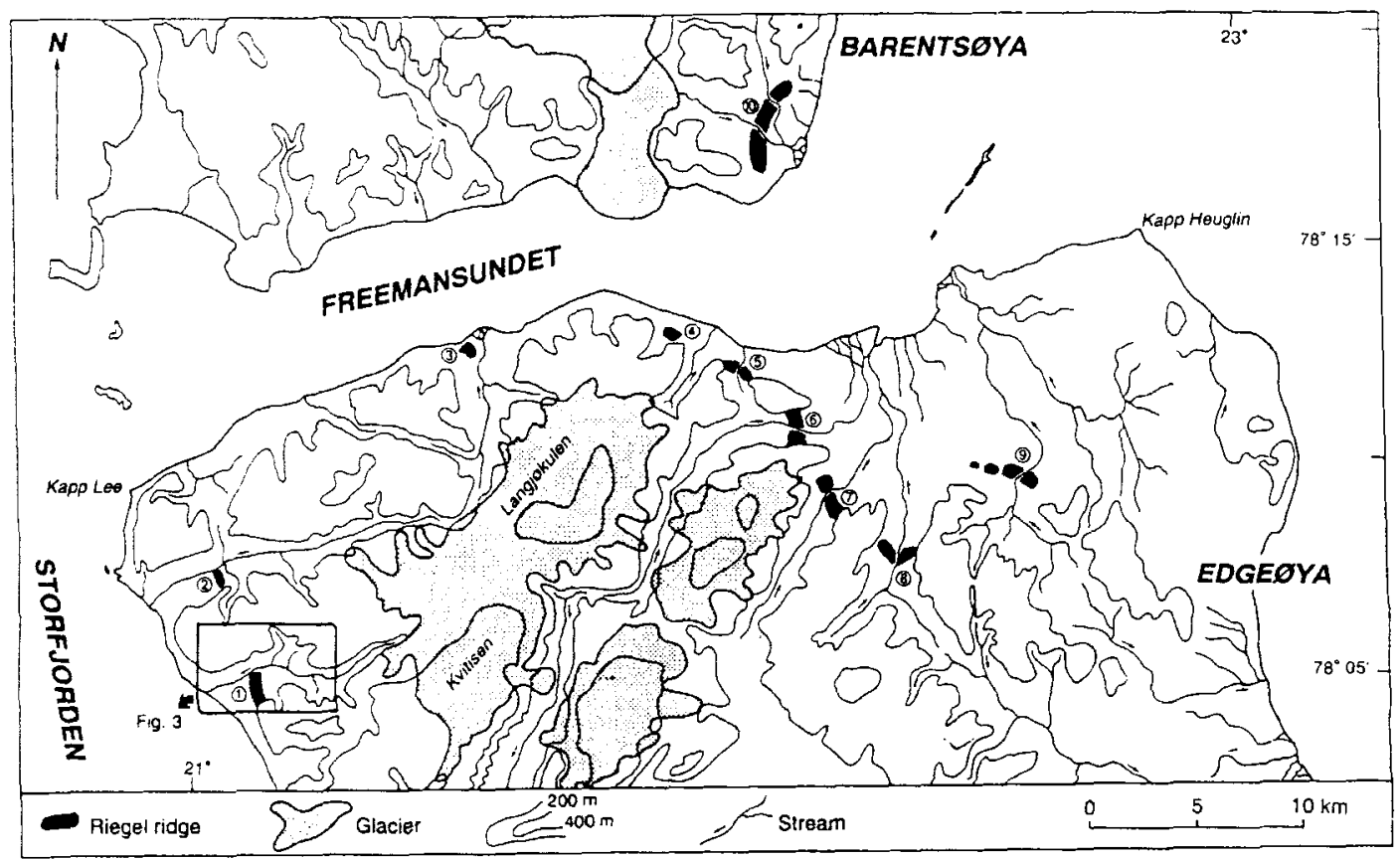

Fig. 2. Vorthern Edgenva and southern Barentsøya. showing general topography, present glacier distribution and the distribution of "riegel" ridges, the latter according to Büdel (1968) and Glaser (1968). Numbers at riegel ridges refer to Table 1, summarising riegel ridge names, altitudes, datings and brief sediment descriptions. 
Table 1. Geographic names, altitudes of crests, datings and sediment descriptions of "riegel" ridges on Edgeøya and Barentsøya according to Büdel $(1968)^{1)}$, Glaser $(1968)^{2)}$ and Nagy $(1984)^{3)}$. For location of ridges, see Fig. 2.

\begin{tabular}{|c|c|c|c|c|}
\hline $\begin{array}{l}\text { Ridge } \\
\text { no. }\end{array}$ & $\begin{array}{l}\text { Geographical } \\
\text { names of riegel } \\
\text { ridges }\end{array}$ & $\begin{array}{l}\text { Alt. of } \\
\text { ridge } \\
\text { ( } \mathrm{m} \text { a.s.l.) }\end{array}$ & ${ }^{14} \mathrm{C}$ datings & $\begin{array}{l}\text { Description of ridge sediments } \\
\text { according to Nagy (1984) except for } \\
\text { ridge no. } 2\end{array}$ \\
\hline 10 & Murnau-riegel ${ }^{1)}$ & $92^{1)}$ & $\begin{array}{l}7,500 \mathrm{BC}^{1)}(\mathrm{ca} \\
9,500 \mathrm{BP})\end{array}$ & Not considered by Nagy. \\
\hline 9 & $\begin{array}{l}\text { Lech-riegel }{ }^{1)} ; \text { East } \\
\text { of Seminovfjella }\end{array}$ & $80^{1)}$ & $\begin{array}{l}7,500 \mathrm{BC}^{1)}(\mathrm{ca} \\
9,500 \mathrm{BP})\end{array}$ & No description. \\
\hline 8 & $\begin{array}{l}\text { Inn-riegel } \\
\text { Raundalen }^{3)}\end{array}$ & $76^{1)} 77^{3)}$ & & $\begin{array}{l}\text { A minimum of } 9 \mathrm{~m} \text { sand with bivalve } \\
\text { shells, overlain by } 14 \mathrm{~m} \text { gravel. }\end{array}$ \\
\hline 7 & $\begin{array}{l}\text { Isar-riegel }^{1)} \\
\text { Fonndalen }^{3)}\end{array}$ & $76^{11} 81^{3)}$ & & $\begin{array}{l}10 \mathrm{~m} \text { sandy and clayey silt, overlain by } \\
8 \mathrm{~m} \text { bedded gravel. }\end{array}$ \\
\hline 6 & $\begin{array}{l}\text { Iller-riegel } \\
\text { Atndalen }^{3)}\end{array}$ & $71^{1)} 75^{3)}$ & & $\begin{array}{l}6 \mathrm{~m} \text { of sandy silt, overlain by } 35 \mathrm{~m} \\
\text { foreset-bedded gravel. }\end{array}$ \\
\hline 5 & $\begin{array}{l}\text { not named }{ }^{1)} \\
\text { Walter } \\
\text { Thymensbukta }\end{array}$ & - & & No description. \\
\hline 4 & $\begin{array}{l}\text { Günz-riegel }{ }^{1 /} \text {; East } \\
\text { of Meodden }^{3 \text { ) }}\end{array}$ & $76^{31}$ & & $\begin{array}{l}\text { A minimum of } 9.5 \mathrm{~m} \text { sand and silt with } \\
\text { bivalve sheils, covered by } 3.5 \mathrm{~m} \text { of } \\
\text { gravel. }\end{array}$ \\
\hline 3 & Würm-riegel ${ }^{1)} ;-^{31}$ & - & & Not considered by Nagy. \\
\hline 2 & $\begin{array}{l}\text { Rosenbergdalen- } \\
\text { riegel }^{23)}\end{array}$ & $80^{1)} 80^{3)}$ & & $\begin{array}{l}13 \mathrm{~m} \text { sand with bivalve shells, overlain } \\
\text { by } 35 \mathrm{~m} \text { of foreset bedded gravel, the } \\
\text { upper part being reworked by wave } \\
\text { action (Glaser 1968). }\end{array}$ \\
\hline 1 & Visdalen-riegel $^{233)}$ & $\begin{array}{l}80-65^{1\}} \\
78-65^{3)}\end{array}$ & $\begin{array}{l}\text { Maximum age } \\
10,190 \pm 320 \\
\mathrm{BP}^{3)}\end{array}$ & $\begin{array}{l}12 \mathrm{~m} \text { parallel bedded sand with bivalve } \\
\text { shells, overlain by } 26.5 \mathrm{~m} \text { of gravel with } \\
\text { foresets dipping towards the SW. } \\
\text { Overlain erosively by } 2.5 \mathrm{~m} \text { of parallel } \\
\text { bedded sandy gravel. }\end{array}$ \\
\hline
\end{tabular}

sition from longshore currents during a period of stable sea level at or slightly before ca $9,500 \mathrm{BP}$. The riegel ridge was thus built up as a submarine bar slightly below the sea level of that period; it was subsequently abraded and its final morphology was formed during the uplift. Glaser (1968) interpreted the Rosenbergdalen and Visdalen ridges (ridges 1 and 2, Fig. 2) as deltas, the former built up to the marine limit from a stream entering the valley from the south and the latter as a subaqueous ice contact delta, deposited directly by glacial meltwater at the snout of a glacier and built up to the marine limit.

Nagy (1984) discussed eight of the riegel ridges of Büdel (1968) and Glaser (1968) and reinvestigated five of these (ridges $1,4,6,7$, and 8 , Fig. 2 and Table 1), giving short descriptions of their stratigraphy. He gave a fairly comprehensive description of the sediments within and distal to the Visdalen ridge. Nagy (1984) rejected Büdel's (1968) riegel interpretation on two main arguments: (1) there was not sufficient time with a stable sea level for the build up of the ridges by longshore currents, and (2) the structures of the ridges are not "typical for beach progradation". He suggested instead that all ridges were subaqueous ice contact deltas, built up to the marine limit by melt water from "valley glaciers descending from an ice sheet covering most of northern Edgeøya" (Nagy 1984, p. 328). Nagy does not comment on the fact that this was also the opinion of Glaser (1968) for the Visdalen ridge. It must also be mentioned that Nagy (1984) excludes ridges that do not fit with the proposed interpretation. For example, he excludes riegel ridge 10 on southeastern Barentsøya (Fig. 2) as the shape of this ridge does not fit with a glacier margin west of it. He also excludes Glaser's (1968) observation from Rosenbergdalen (riegel ridge 2, Fig. 2) that foresets dip towards the north into the main valley from a tributary valley.

Based on the proposed model of ice-contact ridge formation, Nagy (1984) suggests that ridge formation took place during a general halt in the glacier retreat, named the Visdalen Event. Its timing is framed into the early Preboreal due to 


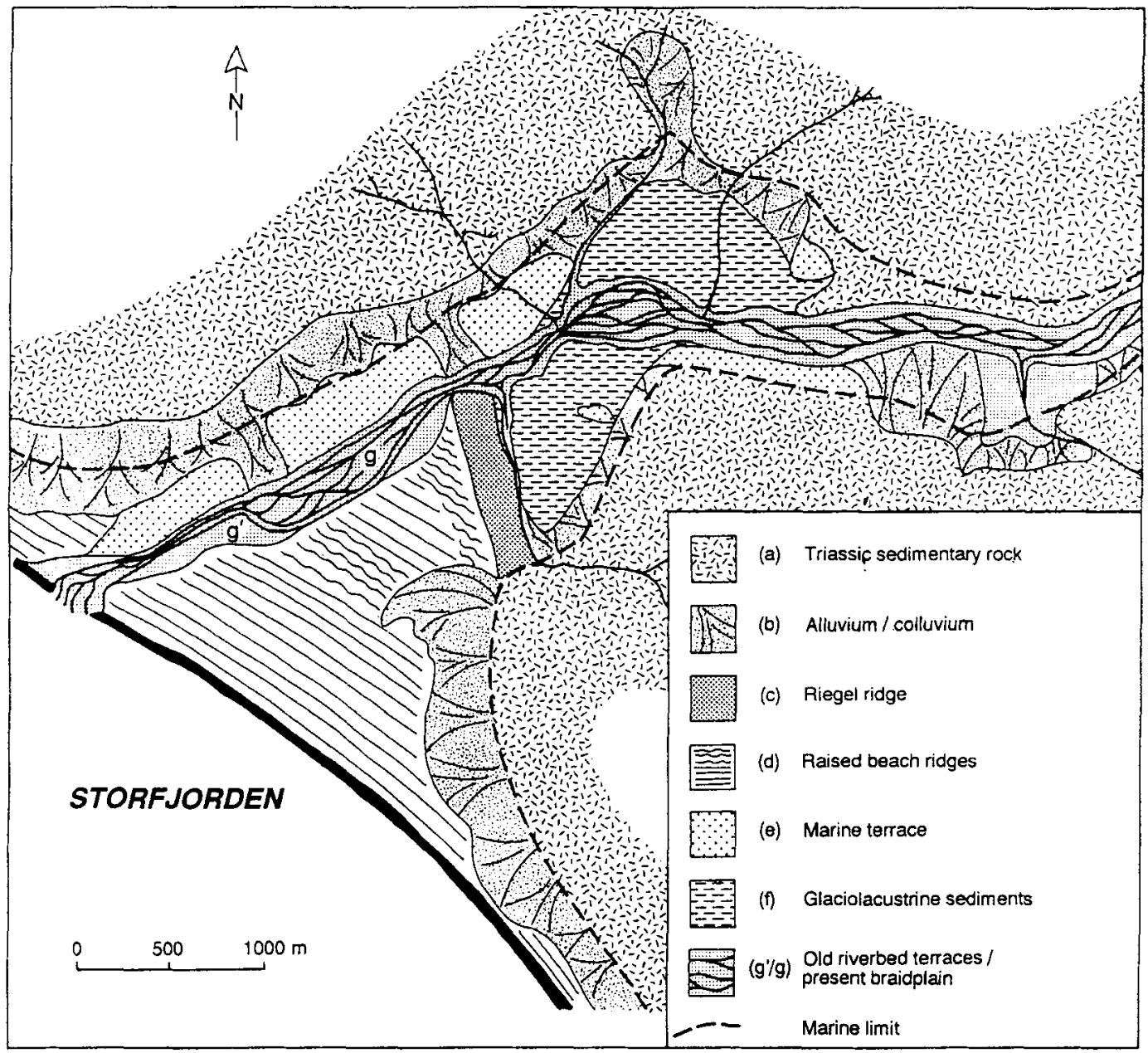

Fig. 3. Geomorphological map of Visdalen. The map is based on air-photo interpretation and field reconnaissance in selected areas

a maximum age, given by a ${ }^{14} \mathrm{C}$ dating on shells in the lowermost part of the marine sediments distal to the Visdalen ridge $(10,190 \pm 230 \mathrm{BP}$, Table 1) and the use of the 9,500 BP isobase map from Boulton et al. (1982), which indicates that the sea level was at $60 \mathrm{~m}$ a.s.l. over northwestern Edgeøya at that time, thus giving a minimum age for the ridge formation.

\section{Geological and geomorphic setting}

The Visdalen valley, which strikes WSW-ENE, is ca $10 \mathrm{~km}$ long and cut into Triassic, almost flat- lying sedimentary rocks. The valley floor and the lower slopes beneath the Quaternary sediments consist of silty shales of the Kongressfjellet and Tschermakfjellet Formations (Winsnes \& Worsley 1981), whereas the upper valley slopes and surrounding plateaux expose the De Geerdalen Formation shales, siltstones and sandstones. These sedimentary rocks are cut by doleritic sills and dykes of lower Cretaceous age.

The flat plateau mountains of northern Edgeøya reach altitudes between $300-500 \mathrm{~m}$ a.s.l. and hold the Langjøkulen/Kvitisen ice cap (Fig. 2) from which outlet glaciers descend into surrounding valleys. Meltwater from this ice cap is 
Fig. 4. The Visdalen "riegel" ridge seen from the north. The stream-cut bluff is site 1715 .

Fig. 5. The marine terrace along the northern valley side of Visdalen and the "riegel" ridge to the left. The terrace is partly eroded down to the right, but rises again further to the east (see Fig. 6).

Glaciolacustrine sediments form the surface in the foreground. Site 2105 is located just behind the intersection of the ridge/ terrace.

Fig. 6 . The northern valley side around site 2104 . The marine terrace has a fanshaped overprint with the apex pointing towards a system of tributary valleys cut into the mountain in the north. Fine-grained glaciolacustrine sediments cling onto the coarsegrained sediments of the main terrace, demarcated with a dashed line. Site 2104 is shown by arrow (1) and site 2103 by arrow (2).
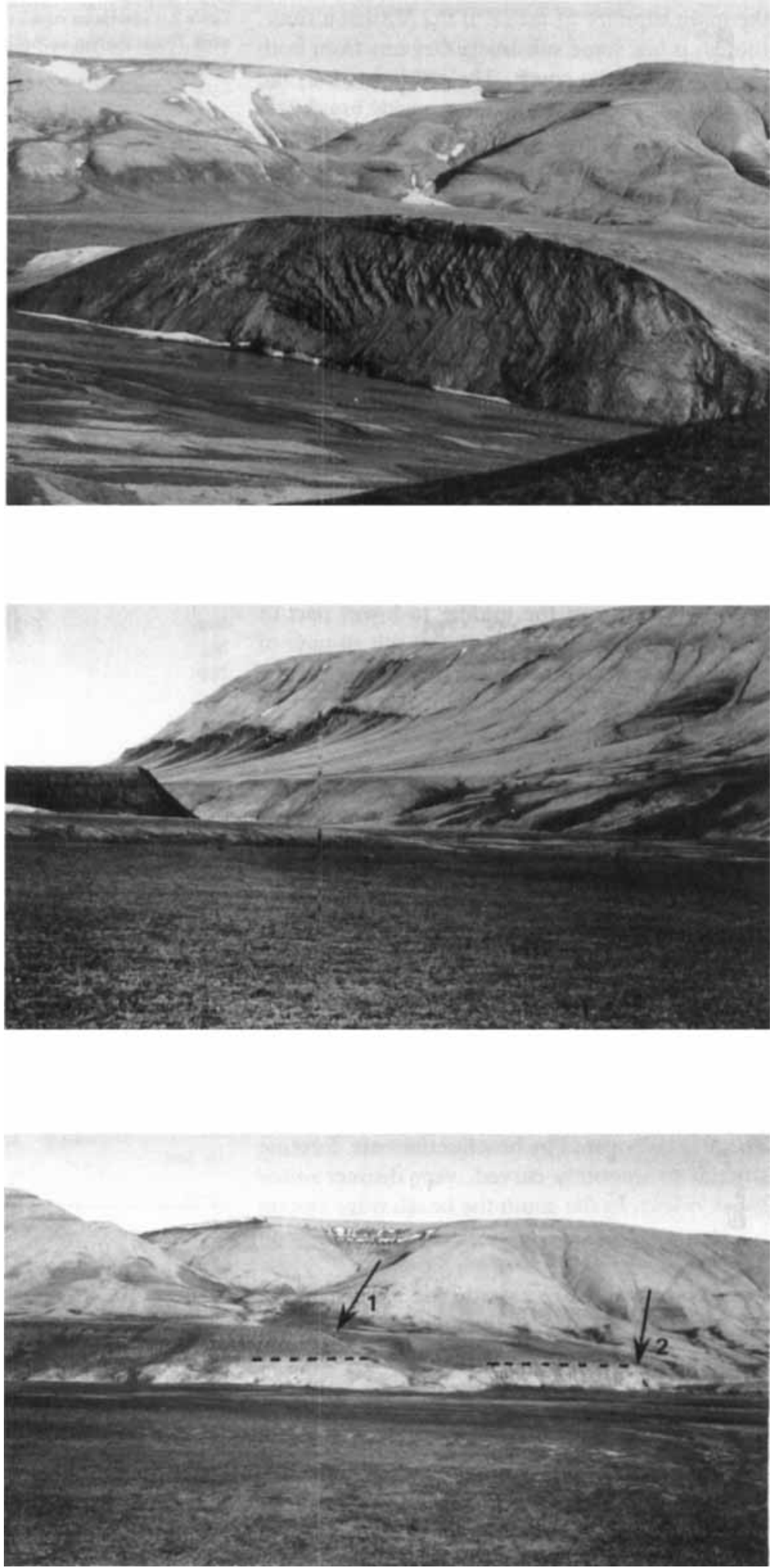
the main supplier of water to the Visdalen river, though it has some subsidiary streams from both the north and the south. The river cuts into the Quaternary sediments, forming a wide braidplain in the upper part of the valley. About $2 \mathrm{~km}$ before its entrance into Storfjorden, it has cut a narrow gorge through the most prominent Quaternary morphological feature of the valley: the transverse "riegel" ridge that once blocked the whole valley.

The main geomorphological/geological elements of Visdalen are shown in Fig. 3 and indicated with the letters a-g. These are briefly described below:

(a) Triassic sedimentary rocks form the upper, steep slopes of the Visdalen valley. Steeper rock faces are formed by outcropping dolerite dykes, specially along the northwestern valley slope.

(b) More or less distinct and active alluvial and colluvial fans form the middle to lower part of the valley slopes. at least down to the altitude of the marine limit. In especially active areas, the alluvial fans have prograded down below the marine limit and thus cover marine and beach sediments.

(c) The riegel ridge, situated at about $2 \mathrm{~km}$ from the present coast, forms a prominent morphologic feature across the valley (Fig. 4). The riegel starts at the southern valley side at an altitude of about $80 \mathrm{~m}$ a.s.l. and slopes towards the north, being at ca $65 \mathrm{~m}$ a.s.l. at its northern tip, where it is ended in a ca $40 \mathrm{~m}$ high cliff at the Visdalen stream. Gently curved beach ridges can be observed on top of the riegel ridge.

(d) West of the riegel ridge is a low-lying plain of marine sediments, gently sloping from $40 \mathrm{~m}$ a.s.l. and down towards the present coast. The plain is covered by beach sediments. forming straight to smoothly curved, very distinct raised beach ridges. In the south the beach ridge system is "transgressed" by alluvial/colluvial fan sediments.

(e) A marine terrace, starting at 70-80 $\mathrm{m}$ a.s.l., can be followed almost continuously along the northern valley side for a distance of approximately three $\mathrm{km}$ (Figs. 5 and 6). The terrace is "transgressed" by alluvial/colluvial fan sediments in its inner part and is also in some areas heavily dissected by streams from the mountain side. Another prominent terrace can be seen along the southern valley side at about $1 \mathrm{~km}$ behind the riegel.
Table 2. Lithofacies codes and their descriptions as used in this work (basic system according to Eyles et al. (1983), modified by Möller (1987))

\begin{tabular}{|c|c|}
\hline $\begin{array}{l}\text { Lithofacies } \\
\text { code: }\end{array}$ & $\begin{array}{l}\text { Lithofacies type } \\
\text { description: Grain size, } \\
\text { grain support system, } \\
\text { internal structures }\end{array}$ \\
\hline $\mathrm{Co}$ & Cobble. -- (as below $)$ \\
\hline Gmm & $\begin{array}{l}\text { Gravel, matrix-supported, } \\
\text { massive }\end{array}$ \\
\hline Geng & $\begin{array}{l}\text { Gravel, clast-supported, } \\
\text { normally graded }\end{array}$ \\
\hline Gcig & $\begin{array}{l}\text { Gravel, clast-supported, } \\
\text { inversely graded }\end{array}$ \\
\hline Gring & $\begin{array}{l}\text { Gravel, clast-supported. } \\
\text { inverse-to-normally graded }\end{array}$ \\
\hline Gcpp & $\begin{array}{l}\text { Gravel, clast-supported, } \\
\text { planar parallel-laminated }\end{array}$ \\
\hline Gcpc & $\begin{array}{l}\text { Gravel, clast-supported, } \\
\text { planar cross-laminated }\end{array}$ \\
\hline Getc & $\begin{array}{l}\text { Gravel, clast-supported, } \\
\text { trough cross-laminated }\end{array}$ \\
\hline $\mathrm{Sm}$ & Sand. massive \\
\hline Sng & Sand. normally graded \\
\hline Sig & Sand. inversely graded \\
\hline Spp & $\begin{array}{l}\text { Sand. planar parallel- } \\
\text { laminated }\end{array}$ \\
\hline Spc & Sand, planar cross- laminated \\
\hline Stc & Sand, trough cross- laminated \\
\hline Sr & Sand, ripple-laminated \\
\hline Sr $(A$, alt. B) & $\begin{array}{l}\text { Sand, subcritically (A) or } \\
\text { supercritically (B) cross- } \\
\text { laminated }\end{array}$ \\
\hline Sd & Sand, draped lamination \\
\hline Sim & Silt. massive \\
\hline Sil & Silt. laminated \\
\hline Sid & Silt. draped lamination \\
\hline $\mathrm{Cm}$ & Clay, massive \\
\hline $\mathrm{Cl}$ & Clay, laminated \\
\hline $\mathrm{D}(\mathrm{G} / \mathrm{S} / \mathrm{Si} / \mathrm{C})$ & $\begin{array}{l}\text { Diamicton, gravelly. sandy, } \\
\text { silty or clayey. One or more } \\
\text { grain-size code letters within } \\
\text { brackets }\end{array}$ \\
\hline $\mathrm{D}(\mathrm{mm}$ & $\begin{array}{l}\text { Diamicton, matrix-supported, } \\
\text { massive }\end{array}$ \\
\hline $\mathrm{D}(\mathrm{ms}$ & $\begin{array}{l}\text { Diamicton, matrix-supported. } \\
\text { stratified }\end{array}$ \\
\hline
\end{tabular}

(f) Glaciolacustrine sediments (Figs. 5 and 6) form wide flat areas behind the riegel, lying at or below $50 \mathrm{~m}$ a.s.l.

(g) The Visdalen stream has cut its way down into the Quaternary sediments and along some stretches also into the sedimentary rocks. forming an active and in places wide braidplain (g). Some old river-bed terraces $\left(\mathrm{g}^{\prime}\right)$ lie slightly above the present braidplain. 
Table 3. Radiocarbon-dated samples from Visdalen. The ages (Rcorr BP) on marine material, used in this text, are corrected for the reservoir-effect ( -440 years; Mangerud \& Gulliksen 1975). Calibrated ages (cal. BP) are calculated according to Stuiver \& Reimer (1993). Sample locations are shown on Fig. 7

\begin{tabular}{|c|c|c|c|c|c|c|c|c|}
\hline $\begin{array}{l}\text { Sed. } \\
\text { unit }\end{array}$ & $\begin{array}{l}\text { Site: } \\
\text { unit }\end{array}$ & $\begin{array}{l}\mathrm{m} \\
\text { a.s.1. }\end{array}$ & Dated material & Lab. no. & $\begin{array}{l}{ }^{14} \mathrm{C} \text { age conv } \\
{ }_{\mathrm{BP}} \pm 1 \sigma\end{array}$ & $\begin{array}{l}{ }^{14} \mathrm{C} \text { age } \\
\mathrm{Rcorr} \\
\mathrm{BP} \pm 1 \sigma\end{array}$ & $\begin{array}{l}{ }^{\mathrm{H}} \mathrm{C} \text { age } \\
\text { cal BP }\end{array}$ & $\delta^{13} \mathrm{C} \%$ \\
\hline III & 2107 & $50 ?$ & Macoma calcarea & AAR-908 & $10,260 \pm 130$ & $9,820 \pm 130$ & 11,026 & -0.96 \\
\hline III & $1806-\mathrm{B} 1$ & 15 & Yoldi hyperborea & AAR- 838 & $10,250 \pm 200$ & $9.810 \pm 200$ & 11,014 & -0.03 \\
\hline III & $1715-B$ & 24 & Mya eruncata & AAR-842 & $10,150 \pm 160$ & $9,710 \pm 160$ & 10,960 & 1 \\
\hline III & $2105-B 2$ & 45 & Mya truncata & Lu-3401i & $10,050 \pm 110$ & $9,610 \pm 110$ & 10.893 & 0.5 \\
\hline III & $2105-B 2$ & 45 & Mya truncata & Lu-3401y & $9,900 \pm 110$ & $9,460 \pm 110$ & 10,576 & 0.5 \\
\hline III & 1811 & 67 & Plant remains (marine) & AAR-843 & $9,915 \pm 220$ & $9,475 \pm 220$ & 10,608 & 19.7 \\
\hline III & 1806-B2 & 19 & Mya truncata & AAR-839 & $9,400 \pm 140$ & $8,960 \pm 140$ & 9,968 & 2.01 \\
\hline III & 1806-B5 & 23 & Macoma calcarea & AAR- 840 & $9,370 \pm 120$ & $8,930 \pm 120$ & 9.949 & 1 \\
\hline IV & $2104-\mathrm{C}$ & 62 & Balanus sp. & AAR- 835 & $10,070 \pm 200$ & $9,630 \pm 200$ & 10,909 & 2.28 \\
\hline IV & $2105-C 1$ & 46 & Mya truncata & Lu-3402 & $9,910 \pm 110$ & $9,470 \pm 110$ & 10,595 & 0.2 \\
\hline IV & $2105-C 2$ & 52 & Balanus sp. & AAR-836 & $9.580 \pm 120$ & $9,140 \pm 120$ & 10,155 & 2.28 \\
\hline V & 1804 & 51 & Plant remains & AAR- 847 & $9,965 \pm 190$ & - & 11,081 & -25 \\
\hline VI & 2103 & 47 & Plant remains & AAR-833 & $8,530 \pm 190$ & - & 9,487 & -25 \\
\hline VI & 2103 & 50 & Plant remains & AAR-834 & $8,690 \pm 250$ & - & 9,644 & -25.73 \\
\hline VI & 1810 & 52 & Plant remains & AAR-844 & $8,640 \pm 170$ & - & 9.533 & -25 \\
\hline VII & 1806 & 24 & Mya truncata & AAR-841 & $10,050 \pm 120$ & $9,610 \pm 120$ & 10,893 & -0.69 \\
\hline VII & 1812 & 68 & Whale bone & AAR-758 & $10,135 \pm 360$ & $9,695 \pm 360$ & 10,952 & -15 \\
\hline VII & 1808 & 78 & Whale bone & AAR-770 & $9,965 \pm 355$ & $9,525 \pm 355$ & 10,803 & -15.4 \\
\hline
\end{tabular}

\section{Methods}

Sediments were logged in scale $1: 10$, but are here presented in a very condensed form. Thin beds have sometimes had to be omitted or, if especially important, slightly exaggerated. Lithofacies codes in logs and text are according to Table 2. Altitude measurements were carried out with a digital altimeter.

Clast-fabric analyses in diamict sediments were performed with 25 or 50 readings of a-axis orientation and dip in each set, measuring only prolate or blade-shaped clasts with an a-axis longer than $3 \mathrm{~cm}$ and having an axial ratio $\mathrm{a} / \mathrm{b} \geqslant 1.5$. Fabric data are plotted on Schmidt equal area lower hemisphere nets. The data sets are statistically evaluated, using the Eigenvalue method of Mark $(1973,1974)$ and modified by Woodcock \& Naylor (1983). Clast lithology was determined on pebble grade clasts $(-2$ to $-4.5 \phi)$ and each set of data comprise between 758 and 1715 counted pebbles.

All ${ }^{14} \mathrm{C}$ dates on marine biogenic material are given as reservoir-corrected ages BP ( -440 years, Mangerud \& Gulliksen 1975) in the text. Full information on ${ }^{14} \mathrm{C}$ dates is given in Table 3 , which also includes calibrated ages BP according to Stuiver \& Reimer (1993).

\section{Lithostratigraphy and sedimentology}

Eleven exposures were examined in detail, together with some minor ones. The locations of all excavated sites and sampling sites are shown in Fig. 7. Based on these excavations, eight major stratigraphic units are recognised, and they suggest the same number of depositional environments, grading into each other in space and time (units $I-V I I I$ ). Logs from eight selected sites are shown in Fig. 8A and B with proposed stratigraphic correlations and environmental interpretations.

\section{Unit I. Alluvial fan-delta deposition}

Unit I sediment was only recognised at site 1815 , an east-facing exposure adjacent to a tributary stream that enters the main Visdalen river from the northeast (Fig. 7).

Description. - Unit I (1815-A, Fig. 8A) is made up of well-consolidated, clast-supported pebbles to boulders with a maximum particle size (MPS) of $20 \mathrm{~cm}$ and a coarse sand matrix. The unit is $>8$ metres thick. The sediment shows a thick, graded 


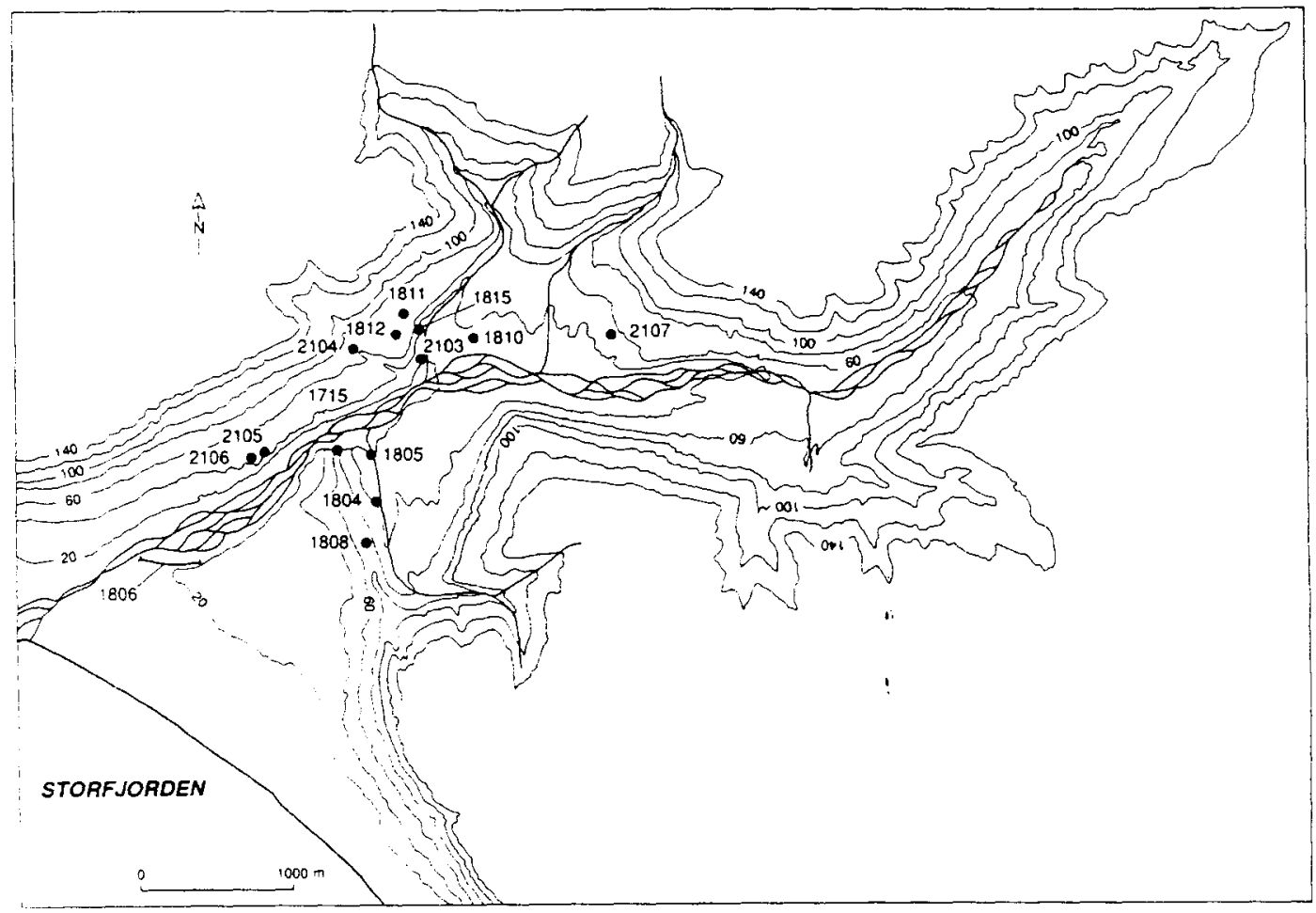

Fig. 7. Visdalen, showing the location of all sites described in the text.

to non-graded, crude bedding with a $33^{\circ}-35^{\circ}$ dip towards the $E$ to ENE. The graded beds are predominantly normally graded, though a few beds show an inverse to normal grading. The sediment is exclusively made up of local dolerite and shale. Dolerites often form outsized, subrounded clasts, whereas shales usually form discto blade-shaped clasts, laying parallel to the bedding planes or with $a / b$-planes imbricated reverse to the general bed dip direction and a-axis orientations parallel to bed dip direction, i.e. an $a(p) a(i)$ fabric in Walker's (1975) notation.

Interpretation. - The beds are interpreted as sediment gravity flow deposits. The predominating, normally graded beds, suggest sedimentation from fully turbulent flows, whereas the nongraded beds indicate cohesionless debris flow with dispersive pressure and clast collision as major supporting mechanisms. Such flows usually show inverse grading with the largest clasts float- ing in the upper part (e.g. Nernec \& Steel 1984; Nemec 1990). The absence of such inverse grading, except a few cases, might suggest a short transport distance, i.e. the sediment did not have enough time to develop the inverse grading. Partly based on negative evidence, such as the absence of fine-grained interbeds and marine molluses, it might be argued that the sediment belongs to a subaerial alluvial-fan depositional system. However, the very steeply-dipping beds and the facies characteristics are not compatible with a subaerial fan (cf. Blair \& McPherson 1994; Nemec \& Postma 1993). Thus it is suggested that the sediment is part of a steep alluvial-fan delta that, in this part, prograded in an easterly direction from a source area considered to be the erosion valley $\mathrm{WNW}$ of the site. The absence of fine-grained interbeds and marine molluscs might simply be due to an extreme rapid sedimentation. The age of the unit is unknown, but it must be pre-Late Weichselian in age as it is overlain by 
Late Weichselian till (see below). This glacial overriding induced the observed high consolidation of the sediment.

\section{Unit II. Glacial erosion and till deposition}

Unit $I I$ is a diamicton, recognised at sites 1815 , 2105, 1715 and 1806 (Fig. 7). At site 1815 (unit 1815-B), the lower boundary cuts erosively into alluvial-fan delta sediments, and at site 2105 the diamicton rests on shale with a gradational, broken-up boundary. The lower boundary of unit II was not exposed at sites 1715 and 1806.

Description. - The thickest exposed succession of unit II diamicton is at site 2105 (Fig. 8A). Here the diamicton is ca $10 \mathrm{~m}$ thick and fines upwards from a massive, sandy gravelly diamicton, rich in boulders and cobbles in its lower part, to a silty sandy diamicton with considerably fewer cobbles and boulders at the top. Large and very angular shale clasts are incorporated in the diamicton along the lower boundary, at places forming a clast-supported framework above the gradational shale/diamicton boundary. A $5-15 \mathrm{~cm}$ thick intrabed of clast-supported sandy pebble gravel could be followed for ca six $m$ in the upper part of the sequence, fading out towards the south.

Cobbles and boulders are all of local provenance. Five lithological analyses of pebble grade clasts show a very high content of the local brown and dark shale (99.9-89\%) throughout the unit (Fig. 9). There is, however, a significant and consistent upward frequency increase in other lithologies, including exotic rock types in small percentages.

Four sets of fabric analyses on unit $I /$ diamicton (Fig. 10) show clustered to slightly equatorial orientations of clast axes, with mean orientations/ dips towards E-ENE. The strength of the preferred orientations ( $\mathrm{S}_{1}$-values) is moderate to strong. Pebbles used for fabric analysis have striated surfaces varying between 53 and $92 \%$ in each set.

Interpretation. - The gradational and consistent upward change in the unit $I I$ diamicton texture and lithology, the high frequencies of striated clasts and the fairly strong preferred clast fabric together support an interpretation of the diamicton being a subglacial (lodgement) till. The sorted sediment bed is thus accordingly interpreted to be due to glaciofluvial deposition in a Nye or Rötlichberger channel at the ice/bed interface. The textural and lithological properties of the lower part of the till suggest quarrying in and entrainment, transport - a very short one and deposition of local bedrock material, probably belonging mostly to the De Geerdalen Formation. The introduction of migmatite and granitic rock clasts in the upper part of the till sequence, together with the decreasing grain size, indicates a subsequent deposition of more fartransported debris. The provenance of the migmatites and granites is probably eastern Spitsbergen or Nordaustlandet (Hjelle \& Lauritzen 1982; Lauritzen \& Ohta 1984), more than $150 \mathrm{~km}$ north of Edgeøya. The fabric analyses and clast lithologies thus indicate that at least the upper part of the unit was deposited by a glacier moving out of Visdalen in a westerly direction towards Storfjorden, and that this glacier was not a local icecap over Edgeøya with topography-controlled outlet glaciers.

\section{Unit III. Glaciomarine - marine deposition}

Unit III sediments were recognised at sites 1806 , $1715,2105,1811,1815$ and 2107 (Fig. 7), with the most comprehensive and diversified successions at sites 2105 and 1806 . The sediments are divided into five subunits (Fig. 8A and B).

Description. - All bedding planes have a low dip, rising to ca $5^{\circ}$ towards a southern sector at the top of the unit. The lowermost part (2105-B1; 1806-B1; Fig. $8 \mathrm{~A}$ and $\mathrm{B}$ ) is characterised by thin $(5-10 \mathrm{~cm})$ beds of silty diamicton $(\mathrm{D}(\mathrm{Si}) \mathrm{mm})$ and massive silt ( $\mathrm{Sim})$, interbedded with very thin $(0.2-1 \mathrm{~cm})$ beds of massive sand $(\mathrm{Sm})$, giving the unit a highly stratified appearance. Dimicton beds at the base are matrix-supported, massive, and have high frequencies of dispersed to clustered pebble grade clasts $(1-3 \mathrm{~cm}$; MPS $15 \mathrm{~cm})$. Outsized clasts usually generate a draped appearance of overlying silt/sand beds. These diamicton beds are interbedded with thin beds of sand and silt, some sand beds just a couple of grains thick, some of them $1-3 \mathrm{~cm}$ thick. The succession continues upwards into $1-10 \mathrm{~cm}$ thick, massive clayey silt beds that have low-frequency occurrences of single floating clasts $(1-3 \mathrm{~cm}$; MPS $10 \mathrm{~cm})$. The silt beds are interbedded with laterally almost continuous but thickening and thinning, $0.1-3 \mathrm{~cm}$ thick beds of fine to medium sand. Pebbles occur dispersed within these beds, and some more con- 


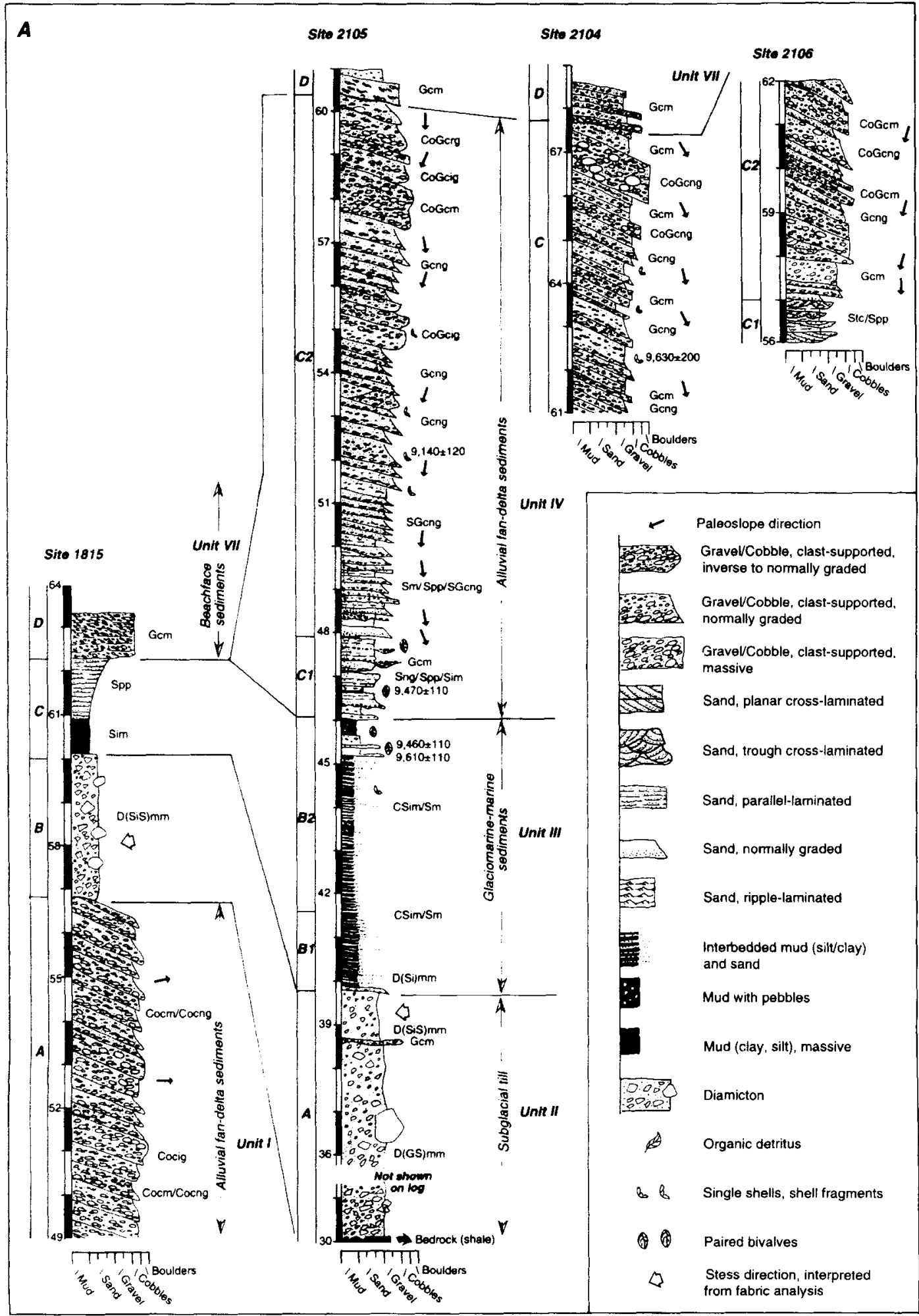

Fig. 8. Logs of selected sediment successions in Visdalen and correlations of recognised lithostratigraphic units (units $1-$ VIII) between the sites. A. Sediment correlation along the northern valley side is a transect from NE to SW. B. Sediment correlation across the "riegel" ridge in a transect from NE to SW. For location of sites. see Fig. 7. 


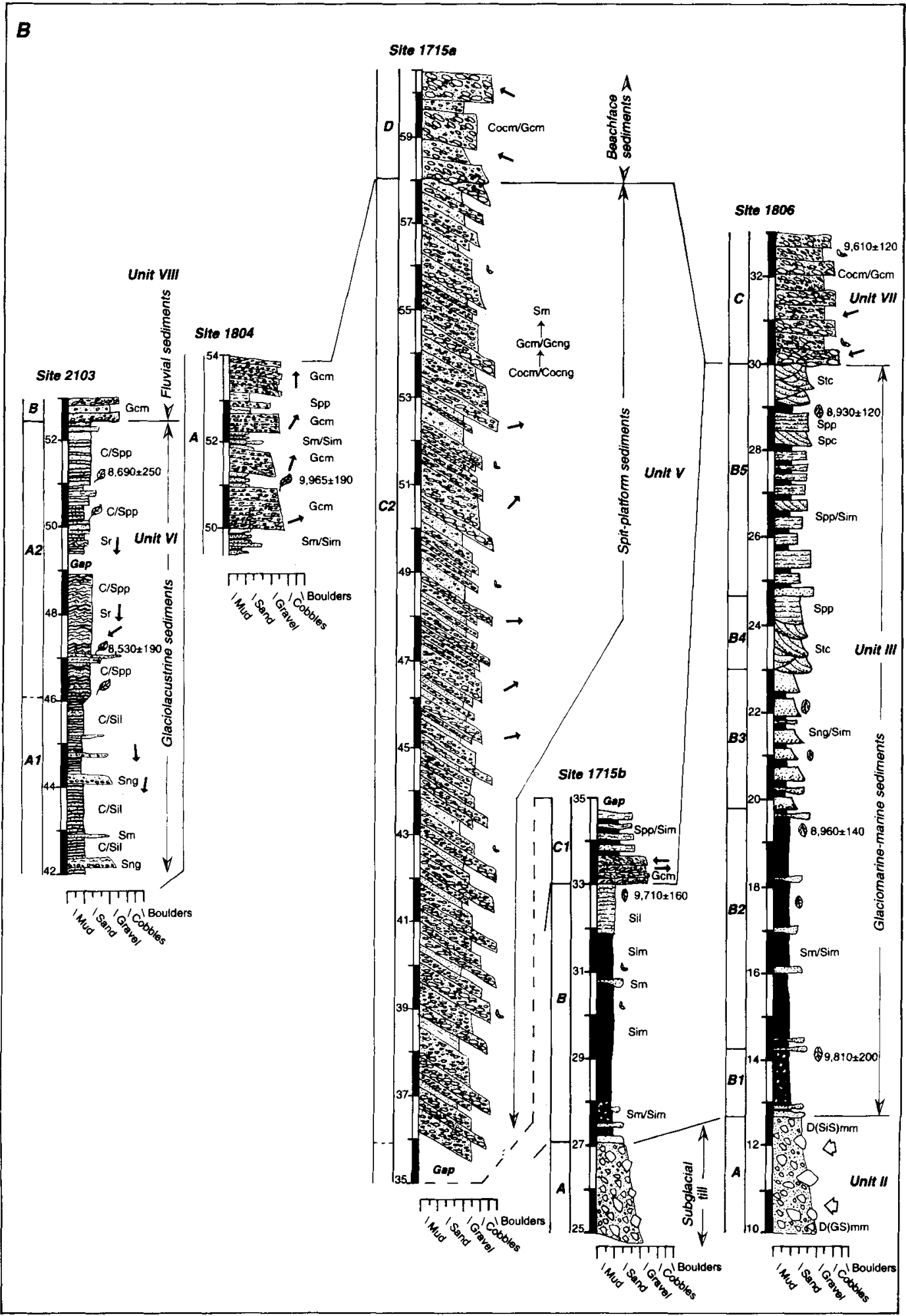




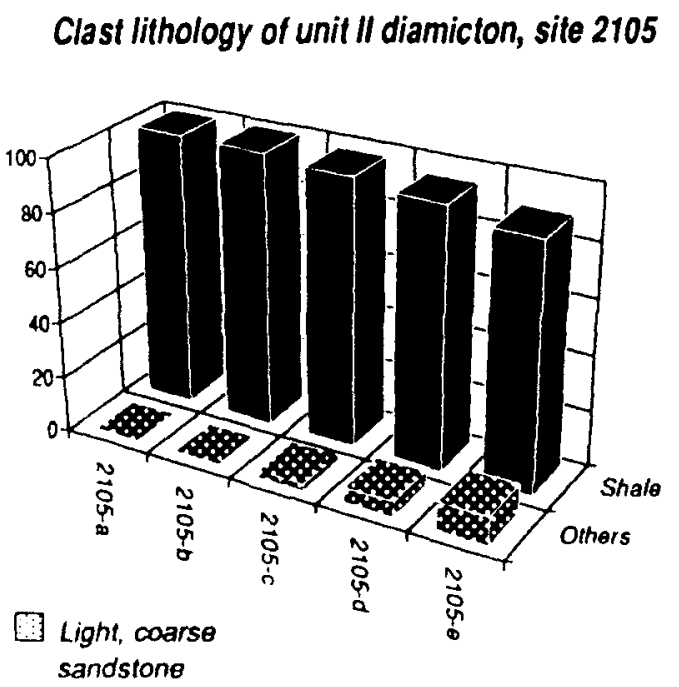

Other sandstones

\section{Composition of clast-group "others", samples c-e}

\section{Migmatites}

\section{Matamorphic rocks}

II Granitic rocks

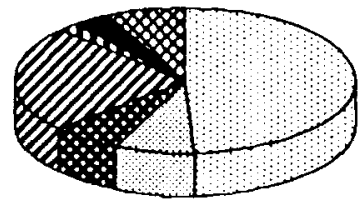

Dolerite

8

\section{Unidentified}

Fig. 9. Lithological analyses of pebble grade clasts from tive samples of the unit Il diamicton at site 2105 (Fig. 7). Sample a is from the lower part of the succession. sample $e$ from the upper part.

tinuous beds grade laterally into extremely thin sand partings, lined with closely spaced pebbles. These beds are associated with some very shallow $(1-2 \mathrm{~cm})$ troughs, eroded into the underlying silt and usually filled with a coarser material.

Upwards the beds thin and fines (2105-B2: Fig. $8 A)$. Clayey silt beds, $1-4 \mathrm{~cm}$ thick, and now without any dispersed pebble clasts are interbedded with very thin $(0.1-1 \mathrm{~cm})$ beds of fine sand with scattered coarse sand and small pebble clasts. Bivalves appear, usually first as single shells, then in increasing frequencies of paired shells, predominantly Mya truncata and Hiatella arctica. At the top of the subunit the sediment coarsens,
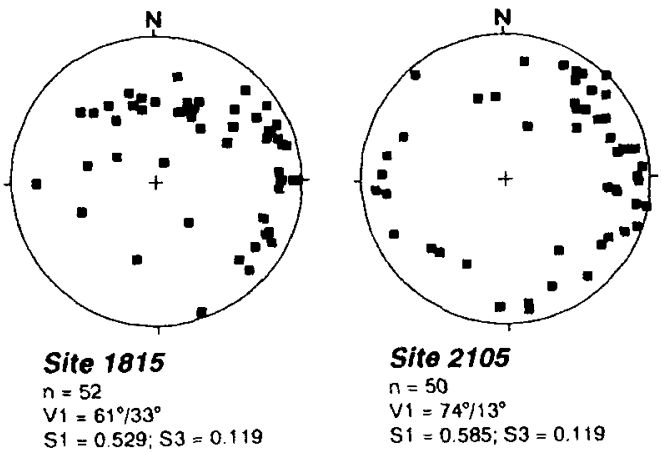

\section{Site 2105}

$n=50$

$V 1=74^{\circ} / 13^{\circ}$

$\mathrm{S} 1=0.585 ; \mathrm{S3}=0.119$

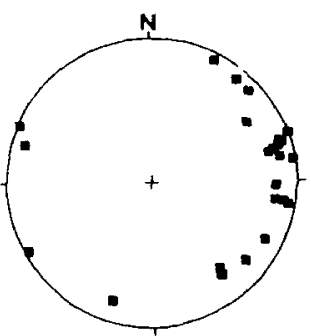

Site 1806-a

$n=25$

$V 1=82^{\circ} / 11^{\circ}$

$\mathrm{S} 1=0.753: \mathrm{S3}=0.023$

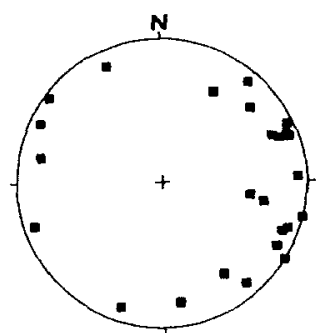

Site 1806-b

$n=25$

V1 $=96^{\circ} / 10^{\circ}$

$\mathrm{S} 1=0.647: \mathrm{S} 3=0.055$

Fig. 10. Fabric analyses of the unit II diamicton at three different sites (Fig. 7)

consisting of thicker beds of sandy silt and silty sand with scattered pebble clasts, interbedded with coarser sand beds, forming a transitional facies to the unit $I V$ sediments at site 2105 (2105C1; Fig. 8A). Paired bivalve shells, some of them in living position, occur frequently and sand-filled burrows, 10-20 cm deep, can be traced from sand beds and down into underlying sandy silt. The latter beds are massive and any primary bedding or lamination has been destroyed due to bioturbation. Seven ${ }^{14} \mathrm{C}$-datings on molluses and plant remains within the lowermost unit III subunits yield ages ranging between $9,810 \pm 200 \mathrm{BP}$ and $8,960 \pm 140$ BP (Table 3 ).

The upper unit $I I I$ succession is only recognised at site 1806 , and is divided into three subunits (1806-B3, B4, B5; Fig. 8B). The logged thickness of these sediments is ca $10 \mathrm{~m}$ and all beds are inclined ca $5^{\circ}$ towards the south. Subunit B3 comprises ca three $m$ of rhythmically interbedded sand and silt. Molluscs occur frequent, with Mya truncata and Macoma calcarea as the dominating species and Hiatella arctica and Montacuta 
terruginosa being less frequent. Burrows, starting from the top of the silt beds and reaching down into the underlying sand beds are common features, some burrows crossing two or more of the sand/silt couplets. Many paired Mya truncata are found in living position in the upper part of these burrows. Subunit B4 shows trough crosslaminated sand in the lower part, followed by planar parallel-laminated sand. There are no signs of biological activity within the subunit.

Subunit B5 is the uppermost ca five $m$ of unit III and like subunit B3 it comp ises rhythmically bedded sand and silt. The sand beds are massive or show planar parallel-lamination, planar crosslamination or through cross-lamination, often with erosive lower bounding surfaces. The sand beds may occur as single beds between an underlying and an overlying silt bed, or occur as cosets or grouped sets of differing facies states between the silt beds. The frequency of burrows is low in the lowermost and uppermost parts, but very high in the middle part of the subunit. A Macoma calcarea shell at the top of the subunit was dated to $8,930 \pm 120$ BP (AAR-840, Table 3).

Interpretation. - The facies states of unit III sediments suggest a glacioaquatic sedimentary environment, gradually changing into a non-glacial marine environment. Taking the shore displacement curve of Bondevik et al. (1995) into account, the interval of the ${ }^{14} \mathrm{C}$ dates indicates water depths of $30-70 \mathrm{~m}$ at the studied sections during deposition of the unit. The lowermost subunit is predominated by deposition of very fine-grained sediment (Sim, CSim) out of suspension from the water column and occasional drops of ice-rafted, coarse debris. The vertical fining of sediments ( $\mathrm{Sim} \rightarrow \mathrm{CSim})$ indicates a decreasing proximity to the sediment source as does the gradual decrease in ice-rafted debris. These sediments, more directly derived from a glacial source, are interbedded with sediment gravity-flow deposits of varying provenance. The diamicton beds $(\mathrm{D}(\mathrm{Si}) \mathrm{mm})$ in the basal part of the unit are interpreted as cohesive debris flow deposits, probably generated by slope failure, remobilising exposed till (unit II) and/or previously deposited beds of clayey silt. sand and gravel. The thin to very thin massive sand beds, occasionally with dispersed pebble grade clasts, are interpreted as deposited from sandy, highdensity turbidity currents. An alternative interpretation is that they emanate from a heavy rain-out of ice-rafted debris. This is, however, contradicted by the observed occurrence of shallow troughs at their bases, eroded down into the underlying silt bed. These turbidity currents are thought to have started as very gravel- to cobblerich flows (see below at interpretation of unit $I V$ sediments). After having deposited their bulk load of gravel, these flows continued down-slope as sandy, high-density flows, but mostly bypassing the areas in question with their main bodies, which were deposited further down-slope. The occurrences of small troughs indicate some scouring at the current/sediment bed interface. The absence of ripple cross-lamination, planar lamination or any inverse grading indicates that there was no deposition from traction or traction carpets (cf. Lowe 1982), but that the deposition took place just as a continuous "rain-out" from suspension from a fully turbulent flow. This resulted in the observed thickening and thinning of the sand beds, some of them passing over into just pebble-strewn, very thin sand partings.

The upward change in facies states (e.g. subunit B2 at site 2105; Fig. 8A) is interpreted to be due to a somewhat more distal position to the sediment sources for both the fine-grained and the coarse-grained sediment beds. The continued decrease in proximity to the glacial sediment source is indicated by a further increase in clay content and the total disappearance of ice-rafted debris. This decreasing proximity may also be indicated by the appearance of, first burrows, then preserved mollusc shells, in its turn indicative of a decreasing sedimentation rate. The decreasing thickness of the sand/pebbly sand interbeds is thought to represent just a lateral and temporal shift in turbidity current frequency and/or capacity.

The overlying sediments (subunits 1806-B3/B4; Fig. $8 \mathrm{~B}$ ) are interpreted as transition zone sediments between off-shore and shore-face depositional environments. ${ }^{14} \mathrm{C}$ dates indicate that this ca $10 \mathrm{~m}$ thick succession was deposited in a very short time period. The sand beds are interpreted as deposited from high-density turbidity currents. possibly generated during storm situations, whereas the silt was deposited in the intervening fair weather periods. Due to this repeated sand burying, parts of the mollusc fauna were eliminated, whereas some molluscs were able to quickly escape upwards through the newly deposited sediment, producing escape traces. In periods with low sedimentation rate there was an 
increase in animal population and thus an increase in bioturbation activity. The subunit B4 sand, more than one metre thick, is suggested to represent a major storm event at which the amount of sand deposited was so high that the fauna in this part of the basin was close to extinction.

\section{Unit IV. Alluvial and colluvial fan-delta deposition}

Unit $I V$ sediments were recognised at sites 2104 , 2105 and 2106 (Fig. 7), with the most comprehensive and diversified succession at site 2105 (Fig. 8A). being ca $14 \mathrm{~m}$ thick. The sediments are divided into two subunits.

Description. - The lower part of the unit (2105. C1; Fig. 8A) is characterised $15-30 \mathrm{~cm}$ thick beds of planar parallel-laminated sand, dipping $6-10^{\circ}$ towards the south. Some beds have erosional lower boundaries with pebble lags, some show an inverse grading with increasing pebble content towards their top. The Spp beds are interbedded with very thin $(\mathrm{ca} 1 \mathrm{~cm})$ silt beds and clastsupported. small to medium pebble gravel beds $(1-3 \mathrm{~cm})$. The latter were found to grade laterally into shallow troughs, a couple of metres wide and $15-20 \mathrm{~cm}$ deep and filled with clast-supported coarse pebble gravel (MPS $10 \mathrm{~cm}$ ). The same stratigraphic level at site 2106 (2106-C1; Fig. 8A) is characterised by an abundance of troughformed. $0.5-1 \mathrm{~m}$ wide erosional scours, grading laterally and vertically into Spp beds. The scours are infilled with massive to normally graded sandy gravel and often a couple of cobbles or boulders lying in the deepest part of the scour troughs.

The planar parallel-laminated sets are often bioturbated in their upper parts, the burrowing activity totally masking former primary, sedimentary lamination. The totally bioturbated zones are usually $5-15 \mathrm{~cm}$ thick when restricted to/within just one sedimentary unit. The burrowing activity has also clearly resulted in down-mixing of silt or pebbles, depending on the facies state of the above-lying bed. Some of these bioturbated beds show very high frequencies of large Mya truncata in the living position with their siphon aperture just beneath overlying pebble lags and with up to $45 \mathrm{~cm}$ long burrows beneath them. A ${ }^{1+} \mathrm{C}$ date on $M y a$ gave an age of $9,470 \pm 110$ B.P. (L.U-3402; Table 3).

The upper part of the unit (2105-C2: Fig. 8A) is characterised by a general upward increase in

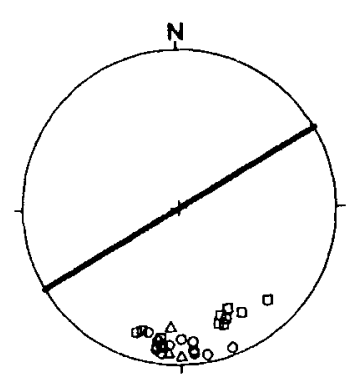

Fig. 11. Foreset dip and plunge of unit IV sediments. Squares: site 2104, $n=10$; circles: site 2105, $n=14$; triangles: site 2106 ; $\mathbf{n}=3$. Thick line shows the trend of the Visdalen valley in its outer part.

grain-size, bed thickness and bedding dips. Bed dips rise from $10^{\circ}$ in the lower part to $28^{\circ}$ in the upper part of the unit. All beds dip in a southerly direction (SSW-SE), which is oblique to perpendicular to the valley trend (Fig. 11). Mean bed thickness increases from $10-15 \mathrm{~cm}$ in the lower part of the unit to $40-50 \mathrm{~cm}$ in the upper part of the unit. though up to one $m$ thick beds occur. Bed thickness increase is matched by a grain-size increase from sand and sandy gravel to cobbly pebble gravel and a general increase in maximum particle size. Clast shape depends on the clast lithology: when shales predominate, clasts are usually disc- to blade-shaped. Coarser sandstones and dolerite predominate the lithology of the cobble-sized clasts, being prolate-shaped and well rounded.

The lower sets usually form clast-supported, normally graded sandy gravel beds, occasionally interbedded with planar parallel-laminated sand. Some sets show trough-shaped erosional surfaces, some of the troughs filled with massive sand with sparse occurrences of floating out-sized pebble clasts. Blade- and disc-shaped clasts in the clastsupported gravel beds show a distinct $a(p) a(i)$ fabric. The Spp beds disappear upwards and the gravel beds become coarser and thicker. The normally graded beds have a coarse clast-supported lower part, in a few cases with an openwork framework, and an increased matrix content towards the top. Large clasts are floating in their sandy gravelly "matrix", showing a-axis orientation parallel to flow and an up-flow imbrication (a (p)a(i) fabric). This most common gravel facies is interbedded with usually thicker, single to multiple sets of inversely graded and inverse-to- 
normally graded pebble gravel and cobbly pebble gravel beds, the inverse grading being usually of the coarse-tail type (inverse grading of the largest clasts only). Some inversely graded beds have out-sized clasts of cobble size, floating in the uppermost part of the bed and protruding into the overlying beds.

Bivalve shells are totally absent, as opposed to their numerous occurrences in the underlying subunit. However, fragments of Balanus shells occur frequently. Shells sampled over a vertical distance of ca one metre at sites 2104 and 2105 yielded ${ }^{14} \mathrm{C}$ dates of $9.630 \pm 200 \mathrm{BP}$ (AAR-835) and $9,140 \pm 120$ BP (AAR-836; Table 3).

Sediment interpretation. - The lower subunit forms a transitional zone between marine deposition and prograding deltaic deposition, the increasing energy level reversing the silt to sand bed thickness ratios compared to unit III. Sedimentary structures, when not destroyed due to bioturbation, indicate deposition from sandy to gravelly, high-density turbidity currents. Some flow units start with trough scouring and erosive pebble lags and continue with settling out of suspension of gravel grade clasts, showed by the normal grading ( $R_{3}$ division; Lowe 1982 ). These beds may continue, as well as other beds start, with traction sedimentation of sand, as showed by the planar parallel-lamination $\left(\mathrm{S}_{1}\right.$ division; Lowe 1982).

The lower part of the unit IV sediments is, compared with the upper part of the unit, distinctly more sandy and deposited with low bed inclinations. These beds are interpreted as distally deposited to the gravelly sediments, discussed below. According to, e.g., Lowe (1982) and Postma et al. (1988), the more sandy-pebbly upper part of a high-density turbidity current is able to by-pass the zone of preferentially coarse gravel deposition, which thus leads to a downslope segregation of grain-size and thus also facies. The lower part of the unit is predominated by massive to graded, thin gravelly sand and sand beds $\left(S_{3}\right.$ divisions) with parallel-laminated sand beds ( $S_{1}$ divisions) as minor facies states, interpreted as deposited from suspension fall-out and traction sedimentation, respectively. More gravelly flows, reaching down-current into this depositional zone, show erosional lower boundaries and shallow scouring into more fine-grained beds.

The alternation of bioturbated/non-bio- turbated zones may be interpreted as the result of rapid sedimentation events, punctuated by periods of slow deposition or non-deposition with vivid bioturbation. Zones with a high occurrence of bivalves preserved in their living position thus also indicate periods of very high sedimentation rates, during which these zones have been very quickly buried and after which the bivalves have not managed to escape upwards. The more common feature with escape traces joining a lower bioturbated zone with an overlying zone indicates that the bivalves have usually managed to escape their buried habitat and establish themselves beneath the new sediment surface.

The facies states of the upper part of unit IV demonstrate a prograding Gilbert-type delta, where high-density, sandy-gravelly turbidity currents and debris-flows from failure of steep delta slopes were dominant in transporting sediment down-slope. Direct suspension sedimentation from fully turbulent flows is shown by the normally graded gravel beds $\left(\mathrm{R}_{3}\right.$ division; Lowe 1982). This facies state is the most frequently occurring in the upper part of unit $I V$. However, the usually very distinct $a(p) a(i)$ fabric suggests that, even if sedimentation was from suspension, clast interaction with development of dispersive pressures were an active process during the late stage of final deposition.

Flow transformation of fully turbid flows will produce variations in sedimentary facies, observed to be of secondary frequency within the unit. Flow deceleration may cause a separation of the flow into a basal, highly concentrated, nonturbulent and more gravelly part (traction carpet) and an upper, less concentrated, sandy to sandygravelly turbulent part (cf. Lowe 1982; Ghibaudo 1992). The grain support mechanisms for the lower part are mainly dispersive pressure due to grain collisions, hindered settling and enhanced buoyant lift, leading to inverse grading of the transported sediment. This grading will be preserved at frictional freezing of these traction carpets if velocity drops below that necessary to maintain the dispersive pressure. A basal freezing of a traction carpet, followed by suspension sedimentation from the upper part of the flow will thus lead to the observed inverse to normally graded beds $\left(R_{2}-R_{3}\right.$ division; Lowe 1982$)$. If the flow transforms to a non-turbulent, i.e., a laminar flow throughout and eventually freezes (en masse or successively), the resulting deposits will be the quite few occurrences of all-through inversely 
graded beds. Alternatively, the inverse grading may be explained due to cohesionless debris flow, initiated by slope failure and with dispersive pressures creating the inverse grading (e.g. Nemec \& Steel 1984; Nemec 1990). The occurrences of cobbles and boulders, floating in the middle to upper part of mainly inversely coarse-tail-type graded gravel beds may be explained by flow separation into two different rheological layers (Postma et al. 1988): large clasts are actually lifted up from a low position within the flow when a basal traction-carpet zone develops and are transported in the boundary zone between the high-density, non-turbulent layer and the abovelying turbulent-flow layer and eventually becomes trapped and deposited in a floating position.

Bivalves disappear totally in the upper subunit. whereas Balanus shell fragments occur in varying frequencies. This indicates a high sedimentation rate, unsuitable for molluscs. Balanus is more resistant to a high-energy environment, but since most shells are fragmented, they probably have been transported together with the gravel from more shallow water.

The interpretations of unit $I V$ sedimentary facies and the geomorphic setting of the sediments suggest that they belong to colluvial and alluvial fan-delta depositional systems. This environmental interpretation will be further elucidated below under discussion

\section{Unit V. Spit-platform progradation}

Unit $V$ sediments were recognised at sites 1715 and 1804 (Figs. 7 and 8B), with site 1715 representing the riegel ridge proper (Fig. 4).

Sediment description. - The lower part of the unit (1715b-Cl; Fig. 8B) forms almost flat-lying, ca $20 \mathrm{~cm}$ thick beds of clast-supported, massive coarse gravel and interbedded sand and silt with floating pebble- to cobble-sized clasts. There is a distinct $a(t) b(i)$ clast imbrication, some beds showing an imbrication towards the west, others to the east. Fragments of Balanus shells occur in the sediment.

The contact to the overlying sediments (1715aC2, Fig. 8B) could not be dug out due to the presence of thick deposits of frozen solifluction material. The exposed part consists of $22 \mathrm{~m}$ of steeply dipping sand to boulder-sized beds, forming rhythmic and repetitive sedimentary facies successions. These are up to one metre thick

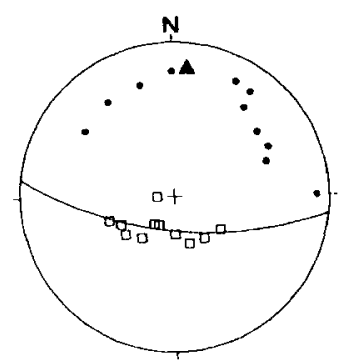

Fig. 12. Plot of bedding planes at site $1715(n=11)$. Filled circles $=$ dip and plunge of foreset beds. Open squares $=$ poles to strike and dip of foreset beds. Girdle $=$ best fitted plane trough poles to strike and dip. Filled triangle $=$ pole to girdle, which defines the axis of the semi-cylindrical bed geometry. This axis dips $20^{\circ}$ towards $\mathrm{N} 6{ }^{\circ} \mathrm{E}$.

and usually show the facies succession $\operatorname{Cocm} /$ Cocng $\rightarrow \mathrm{Gcm} / \mathrm{Gcng} \rightarrow \mathrm{Sm}$, i.e. massive or normally graded, coarse-grained beds, followed by a massive sand bed. The clast- supported, sometimes bouldery (MPS $30 \mathrm{~cm}$ ) cobble beds often have an openwork framework. The clast-supported gravel beds have sand-filled frameworks with usually imbricated disc- and blade-shaped clasts, giving an a(p)a(i) fabric. The general bed dip is $20-35^{\circ}$. but the dip directions vary depending on position within the ridge. Dip direction in the central part is $20^{\circ}$ towards the north, and along the eastern and western sides of the ridge $30-35^{\circ}$ towards the NE and NW, respectively. Thus general bed geometry can be described as semi-cylindrical, with the long axis of the cylinder trending in a S-N direction and plunging $20^{\circ} \mathrm{N}$ (Fig. 12).

Site 1804 is situated on the eastern side of the riegel ridge (Fig. 7) and reveals five metres of foreset-bedded gravel, alternating with beds of sand, silt and clay (Fig. 8B). The lower boundary of the succession was not exposed. The coarse sediments are stratified to massive units of clastsupported, coarse to fine gravel beds, $5-10 \mathrm{~cm}$ thick, and with an $a(p) a(i)$ clast fabric. The gravel beds have a $7-28^{\circ}$ dip towards the $E$ in the lowermost part of the section, turning towards $\mathrm{N}$ in the topmost part. The fine-grained units comprise thin beds of massive to laminated fine sand, silt and clay. Two horizons of moss were seen within these sediments. Macrofossil analysis (Bennike \& Hedenäs 1995) shows a predominance of terrestrial plant and insect remains. One 
sample was AMS-dated, giving an age of $9,965 \pm 190$ BP (AAR-847, Table 3).

Sediment interpretation. - The flat-lying, coarsegrained beds of subunit $\mathrm{C} 1$ at site 1715 , showing distinct but opposite-directed clast imbrications, suggest a current bedload transport and deposition. The stratigraphic position indicates that the deposition took place at water depths around $45 \mathrm{~m}$. Thus these coarse sediments must have been deposited from tidal and/or wind-generated currents.

The overlying coarse-grained, cyclic and steeply inclined beds are interpreted as subaqueous sediment avalanche and gravity flow deposits, deposited as prograding, giant-scale foreset beds. Each full cycle, or parts thereof, may represent one flow event. The lowermost, often openwork Cocm/Cocng bed would thus be the product of debris-fall to grain-flow gravity sorting of clasts moving faster and ahead of the main gravity flow (e.g. Nemec 1990). Alternatively, these beds are the products of longshore current transport of single clasts to a foreset slope, followed by clast-fall down the slope and subsequent deposition. The $\mathrm{Cocm} / \mathrm{Cocng}$ beds are then overlain by a $\mathrm{Gcm} / \mathrm{Gcng}$ bed, deposited out of a fully turbulent, high density turbidity current. Some fine-grained material (sand) may penetrate down into the underlying Cocm/Cocng bed and more or less successfully fills its openwork framework. The coarse-load deposition is then followed by deposition of massive sand out of the tail of the sediment gravity flow during decreasing flow velocity or by individual grain-flow events down the foreset slope.

The interpretations of unit $V$ sedimentary facies and the geomorphic setting of the sediments suggest that they belong to a spit-platform depositional system. This environmental interpretation will be further elucidated below under discussion.

\section{Unit VI. Glaciolacustrine deposition}

Unit VI sediments were recognised at sites 2103 , 1810 and 1805 (Fig. 7), all lying east of the riegel ridge and forming a wide plain in the central part of the tributary valley system, coming into the Visdalen valley from the north and northeast (Fig. 3).

Description. - At site 2103 (Fig. 8B) the unit VI sediment form a rhythmically bedded and coar- sening upwards succession of ca 250 silt to fine sand/clay couplets. In the lower part of the succession the coarse members of the couplets consist predominantly of massive to multiple graded laminae of coarse silt with a mean bed thickness of ca $2.5 \mathrm{~cm}$. The beds change upwards into planar to undulatory parallel-laminated fine sand with a bed thickness ranging between $2-25 \mathrm{~cm}$. The clay members of the couplets are massive, have sharp boundaries to under- and overlying members, and range in thickness between $0.3-2 \mathrm{~cm}$.

Coarse-grained interbeds occur in the lower part of the succession: solitary thin beds of massive pebbly sand and bed sequences with normally graded facies transitions from clast-supported pebble gravel (MPS $2-3 \mathrm{~cm}$ ) above an erosive base to massively pebbly sand and eventually into planar parallel-laminated sand. Minor facies constituents in the upper part of the succession are solitary ripple form-sets and various facies transition from ripple cross-laminated sand to draped lamination and topmost clay layer $\quad(\mathrm{Sr}(\mathrm{A}) \rightarrow \mathrm{Cm} ; \quad \mathrm{Sr}(\mathrm{A}) \rightarrow \mathrm{Sd} / \mathrm{Sid} \rightarrow \mathrm{Cm}$; $\mathrm{Sr}(\mathrm{A}) \rightarrow \mathrm{Sr}(\mathrm{B}) \rightarrow \mathrm{Sd} / \mathrm{Sid} \rightarrow \mathrm{Cm} ; \quad \mathrm{Sr}(\mathrm{B}) \rightarrow \mathrm{Cm})$. The palaeo-current direction according to current ripples was towards the S-SW.

The sediment succession at site 1810 (Fig. 7; not shown on logs) shows a very similar facies assemblage as that of the upper part at site 2103 . However, at site 1805 (Fig. 7; not shown on logs) the sediments form just a uniform, rhythmically bedded succession, comprising a total of 217 massive silt/silty clay couplets. At the base the silt/clay thickness ratio is $1: 1$, gradually changing towards the top where the ratio is $10: 1$.

Organic detritus occurs frequently in the upper parts at sites 2103 and 1810 . Samples analysed by Bennike \& Hedenäs (1995) reveal well-preserved plant remains, indicating short transport. The composition shows a high arctic community, like the one on Edgeøya today, established at the time of deposition of the sediments (Bennike \& Hedenäs 1995). The occurrence of Cennococcum geophilum (a soil fungus) indicates erosion of an established soil profile (Geoffrey Lemdahl, pers. commun. 1992). Three samples were AMSdated to $8,690 \pm 250 \mathrm{BP}, 8,530 \pm 190 \mathrm{BP}$ and $8,640 \pm 170$, respectively (Table 3 ).

Interpretation. - The distinctly rhythmical bedding of unit $V I$ sediments is interpreted as annual varves, i.e. seasonally induced deposition of summer and winter layers, forming varve 
couplets. The time span for lake sedimentation thus was at least in the order of 250 years. Massive to overall graded summer layers at site 1805 and in the lower part of the succession at site 2103 indicate distal suspension settling from overflows/ interflows. However, the frequent occurrence of multiple graded lamination of summer layers also indicates deposition out of suspension from underflows (cf. Ashley 1988). This facies is regarded as the distal equivalent to more proximal underflow deposition of sediments, showing traction-load facies transitions from subcritical to supercritical ripple lamination, continuing into suspension-load draped lamination (site 1810 and the upper part of the succession at site 2103).

The erosive coarse beds at site 2103 are interpreted as sediment gravity-flow deposits, generated by failure and subsequent slumping of lake margin/slope sediments. The graded beds, showing $\mathrm{Gcm} \rightarrow \mathrm{Sm} \rightarrow \mathrm{Spp}$ facies transitions, indicate high velocity, high-density turbulent flows with out of suspension deposition of the basal gravel, followed by upper flow regime traction deposition, resulting in plane bed parallel lamination (e.g. Walker 1975; Lowe 1982; Eyles et al. 1987).

Lithofacies associations, absence of marine fossils, and the introduction of large amounts of terrestrial plant detritus thus show that the marine environment was followed by a distal to intermediate (glacio)lacustrine sedimentary environment, according to the terminology of Ashley (1988). A lake was created for a period of time due to the damming effect of the riegel ridge at the mouth of Visdalen. Altitude measurements indicate that this lake level reached at least an altitude of $52 \mathrm{~m}$ a.s.l. Current ripples show a flow direction into the lake from the $\mathrm{N}-\mathrm{NE}$ along the tributary valleys in the north and not along the main trend of the Visdalen valley. The general upwards coarsening and thickening of summer layers indicates an increasing proximity to a sediment source, e.g. a prograding delta. or a lowering of the lake level. The introduction of organic detritus in the upper parts of the successions is thought to be the result of (melt)water flow over a terrestrial environment before its entrance into the lake, as opposed to a direct icecontact meltwater inflow for the lower parts of the unit.

\section{Unit VII. Beachface deposition}

Unit VII sediments where recognised at sites 1815 .
1811, 2104, 2105, 1715 and 1806 (Figs. 7 and 8A and $B$ ). They usually form the ground surface from the riegel ridge at an altitude of ca $80 \mathrm{~m}$ a.s.1. and westwards down to the present shoreline.

Description. - Unit VII sediments have at all studied sections an erosive contact to underlying sediments and consist of clast-supported, less common matrix-supported, massive pebbly to cobbly gravel. The beds have a low $\left(4-10^{\circ}\right)$ dip towards a NW-SW sector and the shaledominated, flat clasts within the beds sometimes show well-defined seaward-dipping $a(t) b(i)$ imbrication. At some sites the gravel beds are rich in shell fragments, often abraded. Surficial and embedded whale-bones are also frequently occurring. One AMS-date on Mya fragments at a low altitude $(24 \mathrm{~m})$ gave an age of $9,610 \pm 120 \mathrm{BP}$ (AAR-841, Table 3). Two whalebone dates at high altitudes $(68$ and $78 \mathrm{~m}$ ) yielded 9,695 \pm 360 BP (AAR-758) and 9,525 \pm 355 BP (AAR-770), respectively (Table 3 ).

Interpretation. - The erosional contact to underlying sediment, the changed bed inclination and the seaward dipping fabric of pebbles indicate that the unit VII sediments are beach-face sediments, deposited during the emergence of the area and close to the contemporary sea level. The highaltitude whalebone dates are considered to give more or less correct age for those sea levels whereas the ${ }^{14} \mathrm{C}$ date on shell fragments at site 1806, yielding $9,610 \pm 120 \mathrm{BP}$, gives an erroneous age of the beach sediment. This date is significantly older than the age of the uppermost part of the underlying unit (1806-B5; $8,930 \pm 120$ $\mathrm{BP})$ and the shell fragments are thus considered redeposited.

\section{Unit VIII. Fluvial erosion and deposition}

Among the studied sections, unit VIII sediments were recognised only at site 2103 (Figs. 7 and 8B). The sediments form terraces along the present Visdalen river at altitudes lower than ca $55 \mathrm{~m}$ a.s.l.

Description. - The lower boundary of unit VIII sediments (2103-B, Fig. 8B) has an erosive contact to underlying glaciolacustrine sediments. It forms alternating beds of clast-supported pebble gravel (MPS $5 \mathrm{~cm}$ ) and massive gravelly sand and 
sand. Flat clasts show an a/b-plane imbrication towards a northeastern sector.

Interpretation. - The sediments are interpreted as deposited on a fluvial braidplain. Terraces with these fluvial sediments on top were formed during down-cutting into the lacustrine sediments because of the break-through in the damming riegel ridge to the west.

\section{Discussion: depositional evolution of alluvial/colluvial-fan deltas and spit-platforms}

Unit $I V$ and $V$ sediments make up the most conspicuous sediment successions and landforms in the Visdalen valley and have at least one thing in common: they were mainly built up by sediment gravity-flow processes, forming steeply inclined foreset strata. However, based on their geographic positions and sedimentary particularities, the interpretations of the depositional environment of unit $I V$ and $V$ sediments, respectively, are quite different.

The sedimentological interpretations of unit $I V$ sediments, given above, indicate that a glacioaquatic depositional system gave way to a prograding deltaic system, predominated by sediment gravity-flow processes. The palaeocurrent directions of the latter sediments, as indicated from foreset dips, show that they were deposited from the northern valley side at and laterally. to sites 2104-2106 (Fig. 7). Thus they cannot possibly emanate from a retreating glacier, i.e. not represent a series of ice-contact deltas during continuous retreat. The same types of delta foresets were observed along the southern valley side further in-valley (Fig. 3), but deposited towards the $\mathrm{N}$ to $\mathrm{NW}$, i.e. also from the valley side and into the valley. The sediment sources, suggested for these deposits, are the alluvial and colluvial fans that can be seen operating even today along all escarpments. They were probably even more effective immediately after the deglaciation of the area.

The terraces along the valley sides are suggested to be coalescing alluvial and colluvial fandeltas sensu, e.g., Postma \& Cruickshank (1988), Postma (1990) and Blikra (1994), denoting "gravel-rich deltas formed where steep gradient, debris-flow dominated fans have prograded directly into a standing body of water" (Postma
1990). The feeder systems of these deltas - steep fans directly from rock walls and less steep fans from tributary valleys - are thought to have delivered a very coarse load on the lower reaches of a subaerial to sublittoral distributary plain. During high discharge, sediments were possibly also delivered directly onto the subaquatic delta front, generating high-density turbidity currents.

However, the usually well-rounded clasts of pebble to cobble size within the described sediments indicate a substantial wave reworking. It is thus suggested that the main bulk of the sediment was deposited in a beach-face to upper fore-shore environment where it was subjected to abrasion and shape- and size-sorting during successive buildup of sediment thickness. The latter led to localised over-steepening of the foreshore to upper-delta slope, slope instabilities and more or less frequent slope failures, initiating delta-slope high-density turbidity currents. These redistributed and deposited sediment on the lower delta slope and into the pro-delta environment, the latter as indicated by the interbedded gravity flow deposits and (glacio)-aquatic fine-grained suspended sediments of unit III.

The sediment forming unit $V$ and constituting the main part of the transverse valley mouth ridge cannot be directly linked to any colluvial and alluvial fans. However, Meistrell's (1966, 1972) model for spit-platform growth, based on scaled wave tank experiments, can be used as a depositional model for the unit $V$ sediments. Meistrell (1972) demonstrated that sediment, transported coast-parallel by oblique wave action along the coast, was moved out into deeper water if there was a sharp shift in the trend of the beach away from the transport direction. The sediment was then deposited as series of prograding foreset beds, forming a subaqueous platform, built out from the headland in the transport direction. During continued increase in length of the platform three major characteristics were observed: (1) the depth of water above the platform remained constant independent of irregular bed topography, (2) the basic structures of the platform were foreset and topset beds, and (3) a spit ridge was formed on top of the platform that successively emerged above the level of wave action.

Meistrell's concept of spit-platform development was confirmed by Nielsen et al. (1988), based on investigations of a late Pleistocene coarse-grained spit-platform sequence in northern Jylland, Denmark. A typical sediment 
sequence for the depositional spit-platform environment, recognised by Nielsen et al. (1988), was (1) a giant-scaled cross-bedded unit, overlain by (2) a topset unit formed by 3D-dune and bar/ channel migration. Sandy topset sediment was suggested to be transported in the topset bedform system over the shoreface along the spit to the platform front, whereas pebble- and cobble-grade sediment mainly was transported in the foreshore swash-backswash zone to the platform front. Foresets were then suggested to form by sediment avalanche down the platform front. causing a progradation of the platform.

The steeply inclined beds of subunit $\mathrm{C} 2$ at site 1715a (Fig. 8) are interpreted as spit platform beds according to the ideas of Meistrell (1966. 1972) and Nielsen et al. (1988). In Visdalen the headland is situated south of the riegel ridge and progradation of the platform was towards the north. Coarse-grained sediments are suggested to have been transported over the platform and in the swash-backswash zone along the spit to the curved edge of the platform where they were deposited as rhythmically layered giant-scale platform foresets dipping towards NW, N and NE. This transport and deposition may have been enhanced during storm events. The subunit $\mathrm{Cl}$ sediments have previously been interpreted as deposited by tidal/wind generated currents. Tidal currents in and out of the Visdalen palaeo-bay may have been enhanced in front of the prograding spit platform during the successive, and finally nearly total closure of the bay. The foresetbedded gravel sets at site 1804 (Fig. 8B) are in the lee of the riegel ridge and are interpreted as spit-platform gravels, deposited as wash-over fans or as platform foresets at the bay-ward side of the platform. The interfingering fine-grained sediments with moss remains are interpreted as lagoon sediments. deposited in the bay behind the riegel ridge. The ${ }^{14} \mathrm{C}$ date of $9,965 \pm 190 \mathrm{BP}$ shows that the riegel was under construction at that time.

What time frame do we have for the buildup of the riegel ridge and what was the sedimentation rate? The facies model for the spit-platform concept is in it self time-transgressive. The oldest part in the south (ca $80 \mathrm{~m}$ a.s.1.) should have been built up to the marine level at around $10,800 \mathrm{BP}$ in calibrated ${ }^{14} \mathrm{C}$ years according to the shoredisplacement curve of Bondevik et al. (1995). A maximum age for the lowermost platform sediments in the northern and youngest part is given by the dating on $M y a$ in the underlying unit 1715 B (Fig. 8B) sediments: $9,710 \pm 160$ BP $(10,960$ cal. BP; Table 3). The shore-displacement curve of Bondevik et al. (1995) indicates a shoreline at $65 \mathrm{~m}$ a.s.l. at ca $10,500 \mathrm{cal}$. BP, giving a minimum age of platform development in the northern tip of the ridge. This gives, without considering the possible dating errors, a depositional period of ca 460 years for buildup of the riegel ridge in its northernmost part and thus a minimum sedimentation rate of just ca $5 \mathrm{~cm} /$ year. It is however possible that there is a hiatus between sediment units III and $V$, thus increasing the sedimentation rate of the spit-platform sediments.

The environmental interpretations for unit $I V$ and unit $V$ sediments suggest that they were deposited simultaneously, but in two types of depositional environments that had the same sediment source: colluvial and alluvial fans prograding from mountain sides and tributary valleys and into the sea. The spatial distribution of the colluvial- and alluvial-fan deltas (unit IV) shows that these were formed in more sheltered environments, i.e. along mountain/valley sides of bays lving oblique to transverse to the general coastline direction and/or in the interior parts of the former marine bay. However, deltaic buildup along exposed coastal areas, such as along the steep mountainside coast south of the Visdalen palaeobay entrance, was hindered due to powerful longshore drift. The sediments from flanking alluvial fans there were entrained by longshore current and wave action and transported northwards. A subaqueous spit-platform (unit $V$ ) - the riegel was built out at the point for coastline direction change, i.e. at the entrance to the Visdalen bay and in the direction of longshore drift. The buildup of the spit-platform - the riegel -- and the alluvial fan-deltas was time-transgressive within a time frame between $9,710 \mathrm{BP}(10,960 \mathrm{cal}$. BP $)$ and $9.140 \mathrm{BP}(10,155 \mathrm{cal}$. BP $)$. At site 1804 there are some indications that the spit-platform sedimentation was going on as early as $9,965 \mathrm{BP}$ $(11,081 \mathrm{cal}$. BP $)$. These dates thus give a maximum period of $800-1000$ years of deposition for the unit $I V$ and $V$ sediments.

Spit-platform formation occurred during a period of rapid regression (Bondevik et al. 1995), and not during a period of stable sea-level as suggested by Büdel (1968). This suggests that a combination of a considerably larger longshore sediment transport during the Preboreal, as compared with today, and a larger input of glacial 
sediments, sitting on unstable slopes immediately after deglaciation, was at hand and giving the basic prerequisites for spit-platform development. It must not be ruled out that the hydrographic regime of the region was different from today during the early Holocene, a difference that might have been climatically controlled. A larger influx of Atlantic waters in the eastern Svalbard area is indicated by the occurrence of thermophilous molluscs (Salvigsen et al. 1992), and a minimum age of this influx is dated to 8,800 BP according to Hjort et al. (1995). This higher influx of Atlantic waters might have had a considerable effect on the circulation pattern around Edgeøya and Barentsøya and also an effect on the near-shore sedimentation.

The present study clearly rejects the ice-contact depositional model proposed by Nagy (1984) for riegel ridge formation and thus also the basis for the suggested general halt in glacier retreat in the early Preboreal, named the Visdalen Event.

\section{Summary and conclusions}

The interpretations on genesis and depositional environment of the eight recognised lithostratigraphic units, together with datings and relation to shore level, give us the following environmental evolution during the Late Weichselian to early Holocene glaciation and deglaciation of the area.

Unit $I$, interpreted as alluvial-fan delta sediments, is of unknown age, but it can be concluded that these sediments predate the last glacial event. Sea level at the time of deposition must have been $>57 \mathrm{~m}$ above the present sea level, suggesting a sea level typical for a deglaciation. The sediments are thus analogues to the suggested interpretation of the unit IV sediments: an alluvial-fan delta of the Late Weichselian deglaciation.

Unit II is interpreted as a basal till. The scarcity of older deposits and the total predominance of local bedrock lithologies in the lower part of the till indicate that the Visdalen basin was almost swept free and that the glacier actively eroded the basin floor. The introduction upwards in the till of more distant bedrock lithologies shows that the glacier at this stage was not a local icecap over Edgeøya but belonged to a larger glacier system. Till fabric analyses show that this ice flow was westerly, towards the Storfjorden trough.
Unit III is interpreted as deposited in a glaciomarine environment, which gradually evolved into a marine environment. It is suggested that, after deglaciation of Storfjorden, a glacier receded up the Visdalen valley mainly by iceberg calving. The timing of the deglaciation is partly given by our oldest ${ }^{14} \mathrm{C}$ dates of unit III sediments: $9,810 \mathrm{BP}$ at site 1806 and 9,820 BP at site 2107 , ca three $\mathrm{km}$ further up-valley. However, these dates do not date the earliest marine sedimentation. An even earlier date is that of Nagy (1984), made on Musculus discors and Nuculana pernula shells sampled at our site 1806 (unit 1806-B1; Fig. 8B): $10,190 \pm 190 \mathrm{BP}$. The oldest dates in the nearby Rosenbergdalen are 9,885 BP and 9,830 BP (Boulton 1990), thus also indicating a deglaciation of Storfjorden before 10,000 BP (in calendar years somewhere between $11,000-11,500 \mathrm{cal}$. BP).

The earliest glaciomarine deep-water deposition was predominated by suspension sedimentation of clayey silt and frequent deposition of ice-rafted debris. These sediments were interbedded with distal turbidity current sediments, generated from the depocenters of prograding colluvial/alluvial-fan deltas and spit-platform progradation. The depositional environment of unit III changed gradually from proximal glaciomarine to distal glaciomarine and marine environments. With time, due to uplift, the environment successively became predominated by lower shoreface sedimentation, considered distal-lateral to the unit $I V$ depositional environment. Site 1806 shows the most comprehensive sediment succession of this gradual change in depositional environment. The total period for unit III deposition was, taken our youngest date of this unit into account (8,930 BP), approximately 1200 1400 years. These sediments were, according to ${ }^{14} \mathrm{C}$ dates and the shore-displacement curve of Bondevik et al. (1995), deposited at water depths of $30-70 \mathrm{~m}$ and thus below the wave base (cf. Boulton 1990). This is also indicated by the prosperous bivalve fauna, shown by very intensely bioturbated beds and abundant occurrences of especially Mya truncata in living position.

Unit $I V$ and unit $V$ sediments are interpreted as deposited due to colluvial and alluvial fan-delta and spit-platform progradation. Both units were deposited simultaneously in two types of depositional environments suggested to have the same sediment source: colluvial and alluvial fans prograding from mountain sides and tributary valleys and into the sea. These sediments also have their 
final depositional process in common: deposition mainly by sediment gravity flows on a steep subaqueous slope. The fan deltas (unit IV) were fed directly from colluvial and alluvial fans in the Visdalen bay, whereas spit-platform sediments were derived from the steep mountainside coast south of the Visdalen palaeo-bay. We suggest that powerful longshore drift hindered fan-delta buildup; fan sediments were instead entrained by longshore current and wave action and transported northwards and a subaqueous spit-platform (unit $V$ ) - the riegel - was built out at the point for coastline direction change.

Distal to the deposition of the coarse-grained foreset-bedded units $I V$ and $V$ were deposition of predominantly sandy sediment gravity flows, intercalated in distal, deep-water areas with finegrained sediments deposited from suspension (upper part of unit III. which thus is time-transgressive).

Unit VI sediments, interpreted as glaciolacustrine deposits. suggest that a lagoon was developed behind the riegel ridge when this was built up to or slightly below the contemporary sea level, then blocking the Visdalen valley. Sediment facies states show a seasonally induced deposition, i.e. they represent annual varves, and a total of ca 250 varves were measured. Datings on organic detritus in the upper part of the succession indicate that it was deposited sometime between 9,000 and $8,500 \mathrm{BP}$. The contact between glaciolacustrine sediments and underlying marine sediments, predating the riegel blocking of the valley. was not encountered in our exposures. However. the youngest date on marine sediments east of the riegel is $9.475 \pm 220$ (site 1811). leaving it possible that the glaciolacustrine deposition lasted for approximately 1000 years.

Unit VII is interpreted as a beach-face deposit. The marine terraces outside the riegel. built up by alluvial fan-delta progradation were erosively cut and overlain by these sediments during the uplift of the area. Raised beaches cannot be observed on their top surface, which may suggest a low degree of exposure. combined with a high emergence rate (cf. Bondevik et al. 1995). Beachface sediment also lies unconformably on top of riegel sediments. Beachface deposition formed an integrated process with the proposed model for spit-platform (riegel) buildup. During continued uplift well-developed beach ridges were formed on top of the gently sloping marine sediments (unit III) west of the riegel.
Unit VIII sediments are coarse-grained deposits on top of marine and glaciolacustrine sediments behind the riegel ridge, situated on higher altitudes than the present river bed. They are ascribed to fluvial down-cutting and subsequent deposition at successively lower levels, following the erosion across the riegel and the gradual lowing of sea level.

Acknowledgements. - The present study was financially supported by the Natural Science Research Councils of Sweden and Denmark. Helicopter transports were financed by an EC grant to ESF and logistic support was provided by the Norwegian Polar Institute. K. Johansson participated in the fieldwork and made some laboratory work. L. H. Blikra and G. Postma critically read the manuscript and gave valuable and inspiring comments. To these persons and institutions we extend our sincere thanks. This is a contribution to the European Science Foundation (ESF) Polar Network program: Polar North Atlantic Margins, late Cenozoic Evolution (PONAM).

\section{References}

Ashley. G. M. 1988: Classification of glaciolacustrine scdiments. Pp. 243-260 in Goldthwait, R. P. \& Matsch, C. L. (eds.): Genetic Classification of Glacigenic Deposits. Balkema, Rotherdam

Bennike, O. \& Hedenas, L. 1995: Early Holocene land floras and faunas from Edgeøya. eastern Svalbard. Polar Res. 14(2), 205-214.

Blair. T. C. \& McPherson. J. G. 1994: Alluvian fans and their natural distinction from rivers based on morphology. hydraulic processes, sedimentary processes, and facies assemblages. J. Sediment. Res. A64. 450-589.

Blikra. L. H. 1994: Postglacial colluvium in Western Norway: Sedimentology. Geomorphology and Palaeoclimatic record. Unpubl. Dr. Scient. thesis, Unjversity of Bergen, 260 p.

Bondevik. S. Mangerud. J. . Ronnert. L. \& Salvigsen, O. 1995: Postglacial sea-level history of Edgeøya and Barentsøya. eastern Svalbard. Polar Res. 14(2), 153-180.

Boulton, G. S. 1990: Sedimentary and sea level changes during glacial cycles and their control on glacimarine facies architecture. Pp. 15-52 in J. A. Dowdeswell \& J.D. Scourse (eds. ): Glacimarine Environments: Processes and Sediments. Geol. Soc. Lon. Spec. Publ. 53.

Boulton. G. S. Baldwin. C. T., Peacock. J. D., McCabe, A. M. . Miller, G., Jarvis. J., Horsefield, B., Worsley, P., Eyles, N. Chroston, P. N.. Day. T. E.. Gibbard, P., Hare, P. E. \& von Brunn. V. 1982: A glacio-isostatic facies model and amino acid stratigraphy for the late Quaternary events in Spitsbergen and the Arctic. Nature 298, 437-441.

Büdel. J. 1962: Die Abtragungs-Vorgänge auf Spitzbergen im Umkreis der Barents-Insel auf Grund der StauferlandsExpedition 1959/60. Deurch. Geografentag Köln 22.-26. Mai 1961. Tagungsber. 4. Wissensch. Abh., 337-375. SteinerVerlag, Wiesbaden.

Budel. J. 1968: Die junge Landhebung Spitzbergens im Umkreis des Freeman-Sundes und der Olga-Strasse. Würzb. Geogr. Arb. 22/1. $21 \mathrm{pp}$

Eyles. D.. Eyles, C. H. \& Miall. A. D. 1983: Lithofacies types 
and vertical profile models; an alternative approach to the description and environmental interpretation of glacial diamict and diamictite sequences. Sedimentol. 30, 393-410.

Eyles, N., Clark, B. M. \& Clague, J. J. 1987: Coarse-grained sediment gravity flow facies in a large supraglacial lake. Sedimentol. 34, 193-216.

Ghibaudo, G. 1992: Subaqueous sediment gravity flow deposits: practical criteria for their field description and classification. Sediment. 39, 423-454.

Glaser, U. 1968: Junge Landhebung im umkreis des Storfjord (SO-Spitzbergen). Würzburger Geografische Arbeiten 22/II. $22 \mathrm{pp}$.

Hjelle, A. \& Lauritzen, $\varnothing .1982$ : Geological map of Svalbard, $1: 500,000$, sheet 3G, Spitsbergen northern part. Norsk Polarinst. $154 \mathrm{C}$. Oslo.

Hjort, C., Mangerud, J., Adrielsson, L., Bondevik, S., Landvik, J, Y. \& Salvigsen, O. 1995: Radiocarbon dated common mussels Mytilus edulis from eastern Svalbard and the Holocene marine climatic optimum. Polar Res. 14(2), 239-243.

Knape, $\bar{P}$. 1971: C-14 dateringar av höjda strandlinjer, synkrona pimpstensniväer och iakttagelser av högsta kustlinjen på Svalbard. Unpubl. Lic. Dissertation, Department of Physical Geography, Stockholm University. 142 pp.

Lauritzen, Ø. \& Ohta, Y. 1984: Geological map of Svalbard, 1:500,000, sheet $3 \mathrm{G}$, Nordaustlandet. Norsk Polarinst. $154 \mathrm{D}$. Oslo.

Lowe, D. R. 1982: Sediment gravity flows: II. Depositional models with special reference to the deposits of high-density turbidity currents. J. Sediment. Petrol. 52, 279-297.

Mangerud, J. \& Gulliksen, S. 1975: Apparent radiocarbon ages of recent marine shells from Norway, Spitsbergen, and Arctic Canada. Quat. Res. 38, 1-31.

Mark. D. M. 1973: Analysis of axial orientation data, including till fabrics. Bull. Geol. Soc. Am. 84, 1367-1374.

Mark, D. M. 1974: On the interpretation of till fabrics. Geol. 2, 101-104.

Meistrell, F. J. 1966: The Spit-Platform Concept: Laboratory Observations of Spit Development. Unpubl. Masters Thesis, University of Alberta, Edmonton, Alberta. $46 \mathrm{pp}$.

Meistrell, F. J. 1972: The spit-platform concept: laboratory observations of spit development. Pp. 225-283 in M. L. Schwartz (ed.): Spits and Bars. Dowden, Hutchinson \& Ross, Stroudsberg.

Möller, P. 1987: Moraine morphology, till genesis and deg* laciation pattern in the Åsnen area, South-central Småland, Sweden, LUNDQUA Thesis 20, $146 \mathrm{pp}$.

Nagy, J. 1984: Quaternary glaciomarine deposits and foraminifera from Edgeøya, Svalbard. Boreas 13, 319-332.

Nemec, W. 1990: Aspects of sediment movement on steep delta slopes. Pp. $29-73$ in Colella, A. \& Prior, D. B. (eds.): CoarseGrained Deltas. Spec. Publ. Int. Assoc. Sedimentol. 10.

Nemec, W. \& Steel, R. J. 1984: Alluvial and coastal conglomerates: their significant features and some comments on gravelly mass-flow deposits. Pp. 1-31 in Koster, E. H. \& Steel, R. J. (eds.): Sedimentology of gravels and conglomerates. Can. Soc. Petrol. Geol. Mem. 10.

Nemec, W. \& Postma, G. 1993: Ouaternary alluvial fans in southwestern Crete: sedimentation processes and geomorphic evolution. Pp. 235-276 in Marzo, M. \& Puigdefabregas, C. (eds.): Alluvial Sedimentation. Spec. Publ. Int. Assoc. Sedimentol. 17.

Nielsen, L. H., Johannessen, P. N. \& Surluk, F. 1988: A Late Pleistocene coarse-grained spit-platform sequence in northern Jylland, Denmark. Sedimentol. 35, 915-937.

Postma, G. 1990: Depositional architecture and facies of river and fan deltas: a synthesis. Pp. 13-27 in Colella, A. \& Prior, D. B. (eds.): Coarse-Grained Deltas. Spec. Publ. Int. Assoc. Sedimentol. 10.

Postma, G. \& Cruickshank, 1988: Sedimentology of a late Weichselian to Holocene terraced fan delta, Varangerfjord, northern Norway. Pp. 144-157 in Nemec, W. \& Steel, R. J. (eds.): Fan Deltas: Sedimentology and Tectonic Settings. Blackie \& Son.

Postma, G., Nemec, W. \& Kleinspehn, K. L. 1988: Large floating clasts in turbidites: a mechanism for their emplacement. Sediment. Geol. 58, 47-61.

Salvigsen, O., Forman, S. \& Miller, G. H. 1992: Thermophilous molluscs on Svalbard during the Holocene and their paleoclimatic implications. Polar Res. 11, 1-10.

Stuiver, M. \& Reimer, P. J. 1993: Extended ${ }^{14} \mathrm{C}$ data base and revised CALIB $3.0^{14} \mathrm{C}$ age calibration programme. Radiocarbon 35, 215-230.

Walker, R. G. 1975: Generalized facies models for resedimented conglomerates of turbidite association. Geol. Soc. Am. Bull. 86, 737-748.

Wisnes, T. S. \& Worsley, D. 1981: Geological map of Svalbard 1:500,000. Sheet 2G Edgeøya. Norsk Polarinst. 154B. Oslo.

Woodcock, N. H. \& Naylor, M. A. 1983: Randomness testing in three-dimensional data. J. Struct. Geol. 5, 539-548. 
